\title{
Advanced Squamous Cell Carcinoma of the Lung: Current Treatment Approaches and the Role of Afatinib
}

This article was published in the following Dove Press journal: OncoTargets and Therapy

\author{
Edgardo S Santos' \\ Lowell Hart ${ }^{2,3}$
}

'Florida Precision Oncology/A Division of 2 Ist Century Oncology, Florida Atlantic University, Aventura, FL, USA; ${ }^{2}$ Drug Development Unit, Florida Cancer Specialists, Fort Myers, FL, USA; ${ }^{3}$ Wake Forest School of Medicine, WinstonSalem, NC, USA
Correspondence: Edgardo S Santos Florida Precision Oncology/A Division of 2 Ist Century Oncology, Thoracic Oncology, Charles E. Schmidt College of Medicine, Florida Atlantic University,

3585 NE 207th Street, Suite C6-C7,

Aventura, FL 33180, USA

$\mathrm{Tel}+\mid$ 56|-334-2850

Fax +1 305-952-4866

Email edgardo.santos@2Ico.com

\begin{abstract}
Options for the treatment of squamous cell lung carcinoma expanded in recent years with the introduction of the immune checkpoint inhibitors into routine clinical practice in both the first- and second-line settings but are still limited. As a result, pembrolizumab, given either alone or in combination with platinum-based chemotherapy, is now a standard first-line treatment for squamous cell lung cancer. However, few options exist once patients have progressed on immune checkpoint inhibitors and chemotherapy. In this setting, the irreversible ErbB family blocker, afatinib, has a potential role as second or subsequent therapy for some patients. The Phase III LUX-Lung 8 study demonstrated that afatinib significantly prolonged progression-free and overall survival compared with erlotinib in patients with squamous cell lung carcinoma. Notably, retrospective, ad-hoc biomarker analyses of a subset of patients from LUX-Lung 8 suggested that patients with ErbB family mutations derived particular benefit from afatinib, especially those with ErbB2 (HER2) mutations. Afatinib has a manageable and predictable safety profile, and adverse events can be managed with the use of a tolerability-guided dose modification protocol. Until more data are available, afatinib could be considered as a potential second-line treatment option for patients who have progressed on combined pembrolizumab and platinum-based chemotherapy and are ineligible for more established second-line options, or as a third-line option in patients who have received first-line immunotherapy, and second-line chemotherapy or chemotherapy and antiangiogenesis therapy. However, further data are required to support the use of afatinib following immunotherapy. Given that treatment options are limited in both of these settings, investigating an agent with an entirely new mechanism of action is warranted. If available, molecular analysis to identify ErbB family mutations or the use of proteomic profiling could help to further isolate patients who are likely to derive the most benefit from afatinib.
\end{abstract}

Keywords: EGFR, NSCLC, second-line therapy, sequencing

\section{Plain Language Summary}

Patients who have just been diagnosed with the type of non-small-cell lung cancer (NSCLC) known as squamous NSCLC usually receive chemotherapy or an immune checkpoint inhibitor (for example, pembrolizumab). Immune checkpoint inhibitors may be given either alone or in combination. For patients who have stopped responding to immune checkpoint inhibitors and chemotherapy, alternative treatments are limited and needed. One possible option is afatinib, an orally administered drug that specifically targets a receptor in the cell membrane of the tumor cell, called the epidermal growth factor receptor (EGFR). In a large clinical study, patients receiving afatinib lived for longer without disease progression than 
did patients who received an older drug, called erlotinib that also targets EGFR. Patients treated with afatinib also lived for longer overall than did patients who received erlotinib. Evidence from this clinical study and reports of individual patients suggest that patients with certain genetic mutations that are targeted by afatinib gain particular benefit from this drug. While afatinib does cause side effects, the most common of these are generally manageable by reducing the dose and treating the symptoms of the side effects. Further research is required to support the use of afatinib after immune checkpoint inhibitor treatment. However, it is possible that afatinib may be useful for some patients who are no longer gaining any benefit from combination treatment with chemotherapy and pembrolizumab (but are not suited to the other available therapies), and for patients who have received first-line immune checkpoint inhibitors followed by chemotherapy.

\section{Introduction}

Although the treatment of lung adenocarcinoma has progressed considerably in recent years, therapy for squamous cell carcinoma, the second most common type of non-smallcell lung cancer (NSCLC), lags well behind. ${ }^{1}$ As in lung adenocarcinoma, driver mutations are common in squamous cell lung cancer; however, mutations have been found in a large number of genes, including TP53, PIK3CA, CDKN2A, SOX2, CCND2, NOTCH1/2, MET, and FGFR1. ${ }^{2-4}$ Squamous cell lung cancer has a particularly high tumor mutational burden (TMB), even in early-stage disease, with some cohorts displaying more than 200 exon mutations per tumor. ${ }^{5}$ In addition, tumor subclones may exhibit different combinations of mutations. ${ }^{6}$ Alterations in the tumor suppressor genes, TP53 and CDKN2A, are particularly common in squamous cell lung cancer, with studies suggesting that more than half of patients with squamous cell lung cancer carry mutations in one (and potentially both) of these genes. ${ }^{2,4}$ However, as yet, no therapies targeting these mutations have been approved for squamous cell lung cancer. Less commonly, mutations are seen in the genes encoding members of the ErbB family of receptor tyrosine kinases, including the epidermal growth factor receptor (EGFR), ${ }^{4}$ for which targeted therapy is available. However, the nature of the mutations seen in squamous cell lung cancer differs considerably from lung adenocarcinoma, where two types of EGFR mutations (L858R and deletions in exon 19) predominate. ${ }^{4}$ As a result of the highly heterogeneous nature of squamous cell lung cancer and the wide range of mutations present, this tumor is particularly challenging to treat. In this article, we review current treatment options for squamous cell lung cancer, focusing on the role of the ErbB family inhibitor, afatinib, in this therapeutic landscape.

\section{Literature Search Strategy}

During the development of this review, we searched the published literature (English language only) for articles and presentations that reported clinical efficacy and safety of the second-generation EGFR tyrosine kinase inhibitor (TKI) afatinib in patients with advanced squamous cell carcinoma of the lung. Relevant publications were identified by searching the US National Library of Medicine (NLM) PubMed database, using combinations of the search terms [afatinib] AND [NSCLC] OR [squamous lung]. Reports of clinical trials and real-world evidence (case studies) were included. Other relevant publications were identified from citations in the key publications identified via NLM PubMed and from expert guidelines. Further information was obtained from the US prescribing information for afatinib. ${ }^{7}$

\section{Current Treatment Approaches for Advanced/Metastatic Squamous Cell Lung Cancer}

For patients testing positive for sensitizing EGFR mutations, anaplastic lymphoma kinase $(A L K)$ gene rearrangements, ROS proto-oncogene 1 (ROS1) gene rearrangements, $B-R A F$ proto-oncogene, serine/threonine kinase mutations $\left(B R A F^{\mathrm{V} 600 \mathrm{E}}\right)$, or neurotrophic receptor tyrosine kinase (NTRK) gene fusions, therapy options are targeted to the specific genetic aberration, as follows: gefitinib, erlotinib, icotinib, afatinib, dacomitinib, or osimertinib for $E G F R$ mutation-positive patients; crizotinib, ceritinib, alectinib, brigatinib, or lorlatinib for patients with $A L K$ rearrangements; crizotinib, ceritinib, or entrectinib for patients with $R O S 1$ rearrangements; dabrafenib in combination with trametinib for patients with $B R A F^{\mathrm{V} 600 \mathrm{E}}$ mutation; and larotrectinib or entrectinib for patients with NTRK gene fusions. However, as targetable genetic aberrations are not identified in most patients with advanced squamous cell lung cancer, ${ }^{4,8,9}$ systemic chemotherapy and more recently, immunotherapy, are the mainstay of treatment.

First-line therapy in patients without targetable mutations is generally determined by the level of programmed death ligand-1 (PD-L1) detected by immunohistochemical staining of tumor tissue. The use of immunotherapy in the first-line setting is supported by large Phase III studies demonstrating notably extended survival with regimens incorporating immune checkpoint inhibitors (Table 1). Of note, pembrolizumab is used in combination with carboplatin and either paclitaxel or nab-paclitaxel as first-line treatment for patients with metastatic squamous NSCLC, irrespective of PD-L1 
Table I Summary of Key Clinical Data from Studies of Regimens Approved and Recommended in Key Guidelines for the Treatment of Advanced Squamous Cell Lung Cancer

\begin{tabular}{|c|c|c|c|c|c|}
\hline Study & $\begin{array}{l}\text { Number of } \\
\text { NSCLC Patients } \\
\text { in Trial/Number } \\
\text { with Lung SCC }\end{array}$ & Patient Population & Median PFS & Median OS & $\begin{array}{l}\text { Survival HR vs } \\
\text { Chemotherapy } \\
\text { in Lung SCC } \\
\text { Patients } \\
(95 \% \mathrm{Cl})\end{array}$ \\
\hline \multicolumn{6}{|l|}{ First-line treatment } \\
\hline $\begin{array}{l}\text { Pembrolizumab vs } \\
\text { platinum-based } \\
\text { chemotherapy } \\
(\text { KEYNOTE-024) }\end{array}$ & $305 / 56$ & PD-LI TPS $\geq 50 \%$ & $\begin{array}{l}\text { I0.3 vs } 6.0 \\
\text { months; } \\
P<0.00 \text { I }\end{array}$ & 30.0 vs 14.2 months; $P=N R$ & $\begin{array}{l}\text { PFS } 0.35 \\
(0.17-0.7 I)\end{array}$ \\
\hline $\begin{array}{l}\text { Pembrolizumab vs } \\
\text { platinum-based } \\
\text { chemotherapy } \\
\text { (KEYNOTE-042) }^{\prime \prime}\end{array}$ & $1274 / 492$ & PD-LI TPS $\geq 1 \%$ & $\begin{array}{l}\text { TPS } \geq 1 \%: 5.4 \\
\text { vs } 6.5 \\
\text { months; } \\
P=N R \\
\text { TPS I-49\%: } \\
\text { NR }\end{array}$ & $\begin{array}{l}\text { TPS } \geq 1 \%: 16.7 \text { vs } 12.1 \\
\text { months; } H R=0.8 I ; P=0.0018 \\
\text { TPS I- } 49 \%: 13.4 \text { vs } 12.1 \\
\text { months; } H R=0.92\end{array}$ & $\begin{array}{l}\text { NR (SCC patients } \\
\text { were not analyzed } \\
\text { separately) }\end{array}$ \\
\hline $\begin{array}{l}\text { Pembrolizumab + } \\
\text { platinum-based } \\
\text { chemotherapy vs } \\
\text { platinum-based } \\
\text { chemotherapy } \\
(\text { KEYNOTE-407) }\end{array}$ & $559 / 559$ & $\begin{array}{l}\text { Unselected (PD-LI TPS } \\
<1 \% \text { and } \geq 1 \% \text { ) }\end{array}$ & $\begin{array}{l}6.4 \text { vs } 4.8 \\
\text { months; } \\
P<0.001\end{array}$ & $\begin{array}{l}\text { I5.9 vs II } .3 \text { months; } \\
H R=0.64 ; P<0.00 I\end{array}$ & $\begin{array}{l}\text { PFS } 0.56 \\
(0.45-0.70)\end{array}$ \\
\hline $\begin{array}{l}\text { Nivolumab + ipilimumab } \\
\text { vs platinum-based } \\
\text { chemotherapy } \\
(\text { CheckMate 227) })^{13,15}\end{array}$ & $\begin{array}{l}\text { PD-LI } \geq 1 \%: \\
\text { II } 89 / 350\end{array}$ & $\begin{array}{l}\text { Unselected (PD-LI <I\% } \\
\text { and } \geq 1 \% \text { ) }\end{array}$ & $\begin{array}{l}\text { PD-LI } \geq 1 \% \text { : } \\
5 . \text { I vs } 5.6 \\
\text { months; HR } \\
0.82\end{array}$ & $\begin{array}{l}\text { PD-LI } \geq I \%: I 7 . I \text { vs } 14.9 \\
\text { months; } P=0.007\end{array}$ & $\begin{array}{l}\text { PD-LI } \geq 1 \% \text { : OS } \\
0.69(0.52-0.92)\end{array}$ \\
\hline $\begin{array}{l}\text { Atezolizumab vs } \\
\text { platinum-based } \\
\text { chemotherapy } \\
\text { (IMpower I I0) }^{16}\end{array}$ & $554 / 167$ & PD-LI $\geq I \%$ on $\mathrm{TC}$ or IC & $\begin{array}{l}\text { TC3 or IC3 } \\
\text { WT: } 8.1 \text { vs } \\
5.0 \text { months; } \\
P=0.0070\end{array}$ & $\begin{array}{l}\text { TC3 or IC3 WT: } 20.2 \text { vs } 13.1 \\
\text { months; } H R=0.59 ; P=0.0106\end{array}$ & $\begin{array}{l}\text { OS } 0.56 \\
(0.23-1.37) \text { (for } \\
\text { TC3 or IC3 WT) }\end{array}$ \\
\hline \multicolumn{6}{|l|}{ Second-line treatment } \\
\hline $\begin{array}{l}\text { Nivolumab vs docetaxel } \\
(\text { CHECKMATE } 017)^{23}\end{array}$ & $272 / 272$ & $\begin{array}{l}\text { Unselected patients with } \\
\text { progressive disease after } \\
\text { first-line platinum-based } \\
\text { chemotherapy }\end{array}$ & $\begin{array}{l}3.5 \text { vs } 2.8 \\
\text { months; } \\
P<0.00 I\end{array}$ & 9.2 vs 6.0 months; $P<0.00$ I & $\begin{array}{l}\text { PFS } 0.62 \\
(0.47-0.8 I)\end{array}$ \\
\hline $\begin{array}{l}\text { Ramucirumab }+ \\
\text { docetaxel vs docetaxel } \\
(\text { REVEL })^{22}\end{array}$ & $1253 / 328$ & $\begin{array}{l}\text { Unselected patients with } \\
\text { progressive disease after } \\
\text { first-line platinum-based } \\
\text { chemotherapy }\end{array}$ & $\begin{array}{l}\text { Overall } \\
\text { population: } \\
4.5 \text { vs } 3.0 \\
\text { months; } \\
P<0.000 \text { I }\end{array}$ & $\begin{array}{l}\text { Patients with SCC: } 9.5 \text { vs } 8.2 \\
\text { months; HR=0.88 }\end{array}$ & $\begin{array}{l}\text { NR (SCC patients } \\
\text { not analyzed } \\
\text { separately) }\end{array}$ \\
\hline $\begin{array}{l}\text { Atezolizumab vs } \\
\text { docetaxel }(\mathrm{OAK})^{24}\end{array}$ & $850 / 222$ & $\begin{array}{l}\text { Unselected patients with } \\
\text { progressive disease after } \\
\leq 2 \text { previous } \\
\text { chemotherapy regimens }\end{array}$ & $\begin{array}{l}\text { Overall } \\
\text { population: } \\
2.8 \text { vs } 4.0 \\
\text { months; } \\
P=\text { NS }\end{array}$ & $\begin{array}{l}\text { Overall population: } 13.8 \text { vs } \\
9.6 \text { months; } H R=0.73 ; \\
P=0.0003\end{array}$ & $\begin{array}{l}\text { OS } 0.73 \\
(0.54-0.98)\end{array}$ \\
\hline
\end{tabular}

(Continued) 
Table I (Continued).

\begin{tabular}{|c|c|c|c|c|c|}
\hline Study & $\begin{array}{l}\text { Number of } \\
\text { NSCLC Patients } \\
\text { in Trial/Number } \\
\text { with Lung SCC }\end{array}$ & Patient Population & Median PFS & Median OS & $\begin{array}{l}\text { Survival HR vs } \\
\text { Chemotherapy } \\
\text { in Lung SCC } \\
\text { Patients } \\
(95 \% \mathrm{Cl})\end{array}$ \\
\hline $\begin{array}{l}\text { Pembrolizumab } 2 \mathrm{mg} / \mathrm{kg} \\
\text { vs pembrolizumab } \\
10 \mathrm{mg} / \mathrm{kg} \text { vs docetaxel } \\
(\text { KEYNOTE-0I0) }\end{array}$ & $1033 / 222$ & $\begin{array}{l}\text { Patients with PD-LI TPS } \\
\geq 1 \% \text { and progressive } \\
\text { disease after platinum- } \\
\text { based chemotherapy }\end{array}$ & $\begin{array}{l}\text { Overall } \\
\text { population: } \\
3.9 \text { vs } 4.0 \text { vs } \\
4.0 \text { months; } \\
P=N S\end{array}$ & $\begin{array}{l}\text { Overall population: } 10.4 \text { vs } \\
12.7 \text { vs } 8.5 \text { months; } P<0.00 \text { I } \\
\text { for both pembrolizumab } \\
\text { groups vs docetaxel }\end{array}$ & $\begin{array}{l}\text { OS } 0.74 \\
(0.50-1.09) ; P=N S\end{array}$ \\
\hline
\end{tabular}

Abbreviations: $\mathrm{Cl}$, confidence intervals; HR, hazard ratio; IC, tumor-infiltrating immune cells; NR, not reported; NS, not significant; NSCLC, non-small-cell lung carcinoma; OS, overall survival; PD-LI, programmed death-ligand I; PFS, progression-free survival; SCC, squamous cell carcinoma; TC, tumor cells; TPS, tumor proportion score; WT, wild-type.

level. ${ }^{10}$ In addition, pembrolizumab monotherapy may be used as first-line treatment in patients with PD-L1 tumor proportion score (TPS) $\geq 1 \%,{ }^{10,11}$ although monotherapy is generally preferred only when PD-L1 TPS is $\geq 50 \%{ }^{12}$ Recently, the FDA approved two additional first-line therapies: nivolumab plus ipilimumab (PD-L1 $\geq 1 \%)^{13-15}$ and atezolizumab monotherapy in patients with high PD-L1 expression (PD-L1 stained $\geq 50 \%$ of tumor cells [TC $\geq 50 \%$ ] or PD-L1 stained tumor-infiltrating immune cells [IC] covering $\geq 10 \%$ of the tumor area $[\mathrm{IC} \geq 10 \%])^{16,17}$ (Table 1 ). For patients with contraindications to immunotherapy, such as autoimmune disease or previous solid organ transplant, combination cytotoxic chemotherapy is recommended. ${ }^{18}$

Options for second and subsequent treatment lines depend on the first-line therapy; agents with a different mode of action are generally recommended. For patients treated with chemotherapy in the first-line, options include nivolumab or atezolizumab for any level of PD-L1 expression, ${ }^{19,20}$ pembrolizumab if PD-L1 TPS is $\geq 1 \%,{ }^{21}$ and the EGFR TKI, afatinib. ${ }^{7,12}$ For patients who received immunotherapy in the first line, docetaxel combined with ramucirumab has become an established second-line option. ${ }^{12,22-24}$ Further options include docetaxel or gemcitabine monotherapy, platinumbased chemotherapy (if not already received in combination with immunotherapy in the first line), and the ErbB family inhibitor, afatinib may also be considered suitable for further investigation in this setting. ${ }^{7,12}$

\section{The Role of the EGFR/ErbB Pathway in Squamous Cell Lung Cancer}

The human EGFR family is composed of four members that belong to the ErbB protein lineage: EGFR (ErbB1/ human epidermal growth factor receptor [HER]1), ErbB2 (HER2/NEU), ErbB3 (HER3) and ErbB4 (HER4). ${ }^{25}$ These receptor tyrosine kinases bind several growth factors, including EGF and transforming growth factor beta, forming a range of homo- and heterodimers that trigger downstream signaling pathways involved in cellular growth and proliferation. These pathways include the phosphatidylinositol 3-kinase/Akt (PKB) pathway, the Ras/Raf/MEK/ ERK1/2 pathway, and the phospholipase C (PLC $\gamma)$ pathway.

Increased expression or mutations in the ErbB family of receptor tyrosine kinases have been implicated in numerous malignancies, including lung, breast, stomach, colorectal, and pancreatic cancers, resulting in the development of a number of agents specifically targeting these receptors or their ligands (Figure 1). ${ }^{25}$ Although EGFR mutations are relatively rare, ${ }^{4}$ studies suggest that EGFR is often overexpressed in squamous cell lung cancer. ${ }^{26}$ In addition, EGFR gene copy number appears to be elevated in up to a quarter of patients with squamous cell lung cancer, ${ }^{4,27}$ and has been shown to correlate with EGFR expression. $^{26}$ Studies have shown that, in addition to EGFR, other members of the ErbB family (such as ErbB2 and ErbB3) may be over-expressed or mutated in around $20 \%$ of patients with squamous cell lung cancer. ${ }^{28-}$ 32 As a result, agents targeting EGFR have been investigated for possible use in squamous cell lung cancer (Table 2). The SQUIRE study in particular, suggested that EGFR was a valid therapeutic target in squamous cell lung cancer, with statistically significant increases in survival seen with first-line necitumumab plus platinum-based chemotherapy versus chemotherapy alone. ${ }^{33}$ However, in the FLEX and BMS099 studies, which compared treatment outcomes with cetuximab monotherapy or cetuximab 


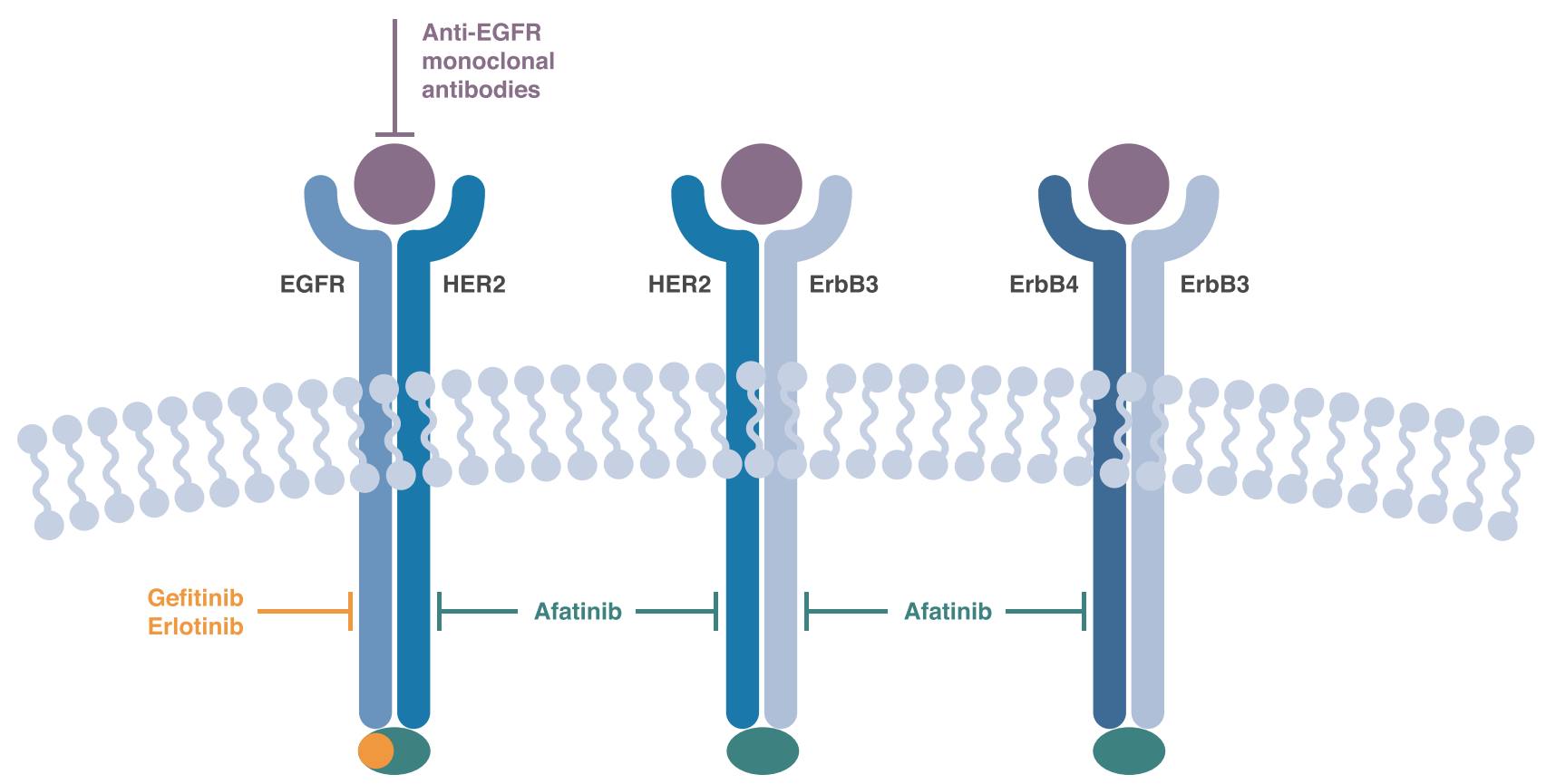

Figure I The ErbB family of receptor tyrosine kinases and the mechanism of action of targeted therapy. Data from these studies. ${ }^{33,95,96}$ Abbreviations: EGFR, epidermal growth factor receptor; HER2, human epidermal growth factor receptor 2.

combined with platinum-based chemotherapy in patients with NSCLC, subset analyses of patients with squamous cell lung cancer indicated no significant difference in overall survival (OS) between the two treatment groups. ${ }^{34,35}$ Biomarker analyses from studies of anti-EGFR monoclonal antibodies suggested that patients with elevated EGFR expression or gene copy number derived greater benefit from anti-EGFR treatment than those with low or no EGFR expression or EGFR amplification, ${ }^{36-38}$ with results from the SQUIRE study suggesting little or no benefit for patients not expressing EGFR. ${ }^{39}$

Based on results from a number of studies in NSCLC that included patients with squamous cell lung cancer, ${ }^{40-43}$ small molecule EGFR TKIs are not recommended for use as monotherapy or in combination with chemotherapy in the first-line treatment of unselected patients with squamous cell lung cancer. However, data from sub-analyses of studies investigating the second- or third-line use of EGFR TKI monotherapy in patients with NSCLC suggest a potential role for these agents in pre-treated patients. Significantly longer survival was seen in ever-smokers with squamous histology who received the reversible, first-generation EGFR-specific TKI, erlotinib, versus placebo, and a reduced risk of progression was observed in squamous cell lung cancer patients overall. ${ }^{44,45}$

In the Phase III TAILOR study, erlotinib was compared with docetaxel as second-line treatment of patients with wildtype EGFR and advanced NSCLC. ${ }^{46}$ Among the overall study population, erlotinib was shown to be inferior to docetaxel, producing significantly shorter OS and progression-free survival (PFS). However, in the subset of patients with squamous cell lung carcinoma, OS was similar in the erlotinib and docetaxel groups (hazard ratio $[\mathrm{HR}]=0.90[95 \%$ confidence interval $\{\mathrm{CI}\}=0.49-1.65]$ ), suggesting that the differences in PFS and OS seen in the overall population were driven by inferior outcomes in the erlotinib arm among patients with adenocarcinoma ( $\sim 69 \%$ of the study population). Although overall survival was similar between the two treatment arms in the squamous cell carcinoma patients, erlotinib appeared to be better tolerated than docetaxel across the entire population.

Another study (PROSE) comparing erlotinib and docetaxel for the second-line treatment of unselected patients with NSCLC used the commercially-available VeriStrat ${ }^{\mathbb{R}}$ serum protein test to classify patients according to whether they were likely to have a good or poor outcome after treatment with EGFR TKIs. ${ }^{47}$ VeriStrat $^{(B)}$ uses matrixassisted laser desorption ionization time-of-flight (MALDITOF) mass spectrometry to measure acute-phase reactant proteins in the blood and assign a "Good" (VS-G) or "Poor" (VS-P) classification. ${ }^{48}$ PROSE was a prospective, randomized, multicenter, Phase III study that stratified patients according to a minimization algorithm by Eastern Cooperative Oncology Group (ECOG) performance status, smoking history, center, and masked pretreatment serum protein test classification. ${ }^{47}$ The proteomic test classification 
Table 2 Summary of Key Clinical Studies of Therapy Targeting EGFR in Patients with Advanced Squamous Cell Lung Carcinoma, Including the Investigation of Biomarkers Predicting Response to Therapy

\begin{tabular}{|c|c|c|c|c|c|c|}
\hline Study & $\begin{array}{l}\text { Number } \\
\text { of NSCLC } \\
\text { Patients in } \\
\text { Trial/ } \\
\text { Number } \\
\text { with Lung } \\
\text { SCC }\end{array}$ & Patient Population & $\begin{array}{l}\text { Median } \\
\text { PFS }\end{array}$ & $\begin{array}{l}\text { Median } \\
\text { OS }\end{array}$ & $\begin{array}{l}\text { Survival HR vs } \\
\text { Chemotherapy } \\
\text { in SCC Patients } \\
(95 \% \mathrm{Cl})\end{array}$ & Predictive Biomarkers \\
\hline $\begin{array}{l}\text { Necitumumab + } \\
\text { gemcitabine-cisplatin } \\
\text { vs gemcitabine- } \\
\text { cisplatin } \\
\text { (SQUIRE) }^{33,39}\end{array}$ & $1093 / 1088$ & $\begin{array}{l}\text { Unselected patients } \\
\text { with lung SCC }\end{array}$ & $\begin{array}{l}5.7 \text { vs } 5.5 \\
\text { months; } \\
P=0.02\end{array}$ & $\begin{array}{l}\text { II.5 vs } 9.9 \\
\text { months; } \\
P=0.01\end{array}$ & $\begin{array}{l}\text { PFS } 0.85 \\
(0.74-0.98) \\
\text { OS (overall } \\
\text { population) } 0.84 \\
(0.74-0.96)\end{array}$ & $\begin{array}{l}\text { Median }{ }^{37} \text { OS significantly } \\
\text { increased ( }>3.9 \text { months) in } \\
\text { necitumumab-treated } \\
\text { patients with tumors } \\
\text { expressing any level of the } \\
\text { EGFR protein compared } \\
\text { with patients not expressing } \\
\text { EGFR }\end{array}$ \\
\hline $\begin{array}{l}\text { Cetuximab + } \\
\text { cisplatin and } \\
\text { vinorelbine vs } \\
\text { cisplatin and } \\
\text { vinorelbine (FLEX) }\end{array}$ & $1125 / 377$ & $\begin{array}{l}\text { Chemotherapy-naïv } \\
\text { patients with NSCLC } \\
\text { and IHC evidence of } \\
\text { EGFR expression in at } \\
\text { least one positively } \\
\text { stained tumor cell }\end{array}$ & $\begin{array}{l}4.8 \text { vs } 4.8 \\
\text { months; } \\
P=\mathrm{NS}\end{array}$ & $\begin{array}{l}\text { II.3 vs } 10.1 \\
\text { months; } \\
P=0.04\end{array}$ & $\begin{array}{l}\text { OS } 0.80 \\
(0.64-1.0)\end{array}$ & NR \\
\hline $\begin{array}{l}\text { Cetuximab plus } \\
\text { carboplatin- } \\
\text { paclitaxel } \pm \\
\text { bevacizumab vs } \\
\text { carboplatin- } \\
\text { paclitaxel } \pm \\
\text { bevacizumab } \\
\text { (SWOG S0819) }^{38}\end{array}$ & $1313 / 32 \mid$ & $\begin{array}{l}\text { Newly diagnosed or } \\
\text { recurrent NSCLC }\end{array}$ & $\begin{array}{l}\text { Overall } \\
\text { population: } \\
4.6 \text { vs } 4.5 \\
\text { months; } \\
P=0.83\end{array}$ & $\begin{array}{l}\text { Overall } \\
\text { population: } \\
\text { I0.9 vs } 9.2 \\
\text { months; } \\
P=0.22\end{array}$ & $\begin{array}{l}\text { PFS } 0.88 \\
(0.70-1.11) \\
P=0.29 \\
\text { OS } 0.85 \\
(0.67-1.07) \\
P=0.17\end{array}$ & $\begin{array}{l}\text { EGFR-FISH positivity was } \\
\text { associated with significantly } \\
\text { improved OS (II } 1.8 \text { vs } 6.1 \\
\text { months; } \mathrm{HR}=0.58[95 \% \\
\mathrm{Cl}=0.39-0.86] ; P=0.01) \text { with } \\
\text { cetuximab treatment vs } \\
\text { chemotherapy }\end{array}$ \\
\hline $\begin{array}{l}\text { Erlotinib vs placebo } \\
(\text { BR2I })^{45}\end{array}$ & $587 / 222$ & $\begin{array}{l}\text { Disease progression } \\
\text { after first- or second- } \\
\text { line chemotherapy }\end{array}$ & $\begin{array}{l}\text { SCC } \\
\text { patients: } \\
2.3 \text { vs } 1.8 \\
\text { months; } \\
P=N R\end{array}$ & $\begin{array}{l}5.6 \text { vs } 3.6 \\
\text { months; } \\
P=N R\end{array}$ & $\begin{array}{l}\text { PFS } 0.48 \\
(0.35-0.67) \\
\text { OS } 0.60 \\
(0.44-0.82)\end{array}$ & NR \\
\hline $\begin{array}{l}\text { Erlotinib vs } \\
\text { docetaxel } \\
\text { (TAILOR) }^{46}\end{array}$ & $219 / 54$ & $\begin{array}{l}\text { Wild-type EGFR and } \\
\text { recurrence/progression } \\
\text { after platinum-based } \\
\text { chemotherapy }\end{array}$ & $\begin{array}{l}\text { Overall } \\
\text { population: } \\
2.4 \text { vs } 2.9 \\
\text { months; } \\
P=0.02\end{array}$ & $\begin{array}{l}\text { Overall } \\
\text { population: } \\
5.4 \text { vs } 8.2 \\
\text { months; } \\
P=0.05\end{array}$ & $\begin{array}{l}\text { PFS } 0.57 \\
(0.32-1.03) \\
\text { OS } 0.90 \\
(0.49-1.65)\end{array}$ & $\begin{array}{l}\text { KRAS mutation was not } \\
\text { associated with prognosis }\end{array}$ \\
\hline $\begin{array}{l}\text { Erlotinib vs } \\
\text { pemetrexed or } \\
\text { docetaxel (PROSE) }\end{array}$ & $263 / 47$ & $\begin{array}{l}\text { Advanced NSCLC and } \\
\text { progression during or } \\
\text { within } 6 \text { months after } \\
\text { first-line platinum-based } \\
\text { chemotherapy }\end{array}$ & NR & $\begin{array}{l}7.7 \text { vs } 9.0 \\
\text { months; } \\
P=0.15\end{array}$ & $\begin{array}{l}\text { PFS NR } \\
\text { OS } 1.08 \\
(0.75-1.57)\end{array}$ & $\begin{array}{l}\text { Patients classified as VS-P } \\
\text { had shorter OS on erlotinib } \\
\text { than chemotherapy } \\
(\mathrm{HR} 1.72[95 \% \mathrm{Cl} \\
\mathrm{I.08-2.74];} P=0.022) \text {. No } \\
\text { difference in OS between } \\
\text { treatments among VS-G } \\
\text { patients }\end{array}$ \\
\hline
\end{tabular}

(Continued) 
Table 2 (Continued).

\begin{tabular}{|c|c|c|c|c|c|c|}
\hline Study & $\begin{array}{l}\text { Number } \\
\text { of NSCLC } \\
\text { Patients in } \\
\text { Trial/ } \\
\text { Number } \\
\text { with Lung } \\
\text { SCC }\end{array}$ & Patient Population & $\begin{array}{l}\text { Median } \\
\text { PFS }\end{array}$ & $\begin{array}{l}\text { Median } \\
\text { OS }\end{array}$ & $\begin{array}{l}\text { Survival HR vs } \\
\text { Chemotherapy } \\
\text { in SCC Patients } \\
(95 \% \mathrm{CI})\end{array}$ & Predictive Biomarkers \\
\hline 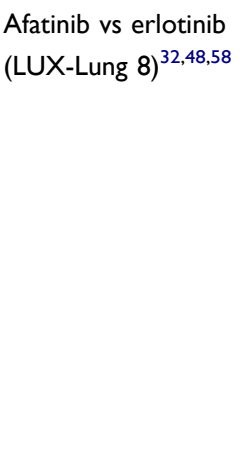 & 795/795* & $\begin{array}{l}\text { Lung SCC and } \\
\text { progression after } \\
\text { platinum-based } \\
\text { chemotherapy }\end{array}$ & $\begin{array}{l}2.6 \text { vs } 1.9 \\
\text { months; } \\
P=0.01\end{array}$ & $\begin{array}{l}7.9 \text { vs } 6.8 \\
\text { months; } \\
P=0.008\end{array}$ & $\begin{array}{l}\text { PFS } 0.8 \mathrm{I} \\
(0.69-0.96) \\
\text { OS } 0.8 \mathrm{I} \\
(0.69-0.95)\end{array}$ & $\begin{array}{l}\text { In afatinib- but not erlotinib- } \\
\text { treated patients, median } \\
\text { PFS and OS were longer in } \\
\text { those with ErbB mutations } \\
\text { vs those without; HER2 } \\
\text { mutation may predict better } \\
\text { outcomes with afatinib vs } \\
\text { erlotinib; EGFR } \\
\text { overexpression did not } \\
\text { predict PFS or OS benefit } \\
\text { with afatinib vs erlotinib }\end{array}$ \\
\hline $\begin{array}{l}\text { Cetuximab vs } \\
\text { cetuximab plus } \\
\text { taxane/carboplatin } \\
(\text { BMS 099) }\end{array}$ & $676 / 132$ & $\begin{array}{l}\text { Chemotherapy-naïve } \\
\text { patients with advanced } \\
\text { NSCLC }\end{array}$ & $\begin{array}{l}4.40 \text { vs } 4.24 \\
\text { months; } \\
P=0.236\end{array}$ & $\begin{array}{l}9.69 \text { vs } 8.38 \\
\text { months; } \\
P=0.169\end{array}$ & $\begin{array}{l}\text { PFS } 0.70 \\
(0.47-1.05)^{\dagger} \text { OS } \\
0.873 \\
(0.599-1.275)\end{array}$ & NR \\
\hline
\end{tabular}

Notes: *32 patients had mixed histology; ${ }^{\dagger}$ Subset variable not prespecified in the statistical analysis plan.

Abbreviations: BMS, Bristol-Myers Squibb; Cl, confidence interval; EGFR, epidermal growth factor receptor; FISH, fluorescence in situ hybridization; HR, hazard ratio; IHC, immunohistochemical; ITT, intent to treat; NR, not reported; NSCLC, non-small-cell lung cancer; OS, overall survival; PFS, progression-free survival; SCC, squamous cell carcinoma; VS-G, Veristrat ${ }^{\circledR}$-good; VS-P, Veristrat ${ }^{\circledR}$-poor.

was masked for patients, and investigators who gave treatments, and treatment allocation was masked for investigators who generated the proteomic classification. This study showed no differences in OS between treatment groups in patients classified as VS-G (adjusted $\mathrm{HR}=1.06 \quad[95 \%$ $\mathrm{CI}=0.77-1.46], P=0.714)$. However, OS was longer with docetaxel than erlotinib in patients classified as VS-P ( $\mathrm{HR}=1.72[95 \% \mathrm{CI}=1.08-2.74], P=0.022)$, indicating that chemotherapy is a better choice in these patients. ${ }^{47} \mathrm{~A}$ more recent randomized, Phase III study, conducted in patients with advanced squamous cell lung carcinoma supported these findings, with comparable PFS and OS with erlotinib and docetaxel seen in VS-G patients. ${ }^{49}$ In this study, however, no difference in survival between the treatment arms was seen in patients classified as VS-P. Across the entire study population and within each treatment arm, survival was significantly longer in VS-G patients compared with VS-P patients (median OS, 8.2 versus 5.2 months).

\section{Clinical Experience with Afatinib in Patients with Squamous Cell Lung Cancer}

Afatinib is a second-generation, irreversible ErbB family blocker that inhibits signaling from all ErbB hetero- and homodimers, ${ }^{50}$ conferring a wider inhibitory profile than first-generation, reversible EGFR-specific agents such as erlotinib and gefitinib. ${ }^{51}$ Afatinib has shown considerable efficacy in patients with EGFR mutation-positive NSCLC, and is approved as first-line treatment in this indication. ${ }^{7}$ In patients with NSCLC and sensitizing mutations in the $E G F R$ gene, afatinib has been shown to significantly prolong median PFS compared with platinum-based chemotherapy, ${ }^{52,53}$ and a significant OS improvement has been observed with afatinib in patients with tumors harboring the exon 19 deletion (Del19) EGFR mutation. ${ }^{54}$ Further, the randomized Phase IIb LUX-Lung 7 trial demonstrated that afatinib was associated with 
significantly longer PFS than gefitinib. ${ }^{55}$ Afatinib is also the only EGFR TKI with United States Food and Drug Administration (US FDA) approval for uncommon EGFR mutations based on PFS and response rate. ${ }^{7}$

Although afatinib is not recommended as first-line therapy for unselected patients with squamous cell lung cancer and wild-type $E G F R,{ }^{12,18}$ it has demonstrated efficacy as second-line therapy in patients with metastatic squamous cell lung cancer following progression on platinum-based chemotherapy, and is approved by the US FDA for use as monotherapy in this patient population. ${ }^{7}$ However, despite the US FDA approval status, the inclusion of afatinib as a second-line treatment option for patients with squamous cell lung cancer varies across treatment guidelines, reflective of the changing treatment landscape in recent years. For example, afatinib is no longer included as a second-line treatment option for patients with metastatic squamous cell non-small-cell lung cancer in the NCCN Clinical Practice Guidelines In Oncology (NCCN Guidelines ${ }^{\circledR}$ ) Version $6.2020 .{ }^{56}$ Conversely, the latest ESMO Clinical Practice guidelines (September 2019) state that afatinib "could be a therapeutic option" for patients with advanced squamous cell lung cancer with unknown or wild-type EGFR status progressing on/after chemotherapy, who are unfit for further chemotherapy or immunotherapy. ${ }^{57}$

\section{LUX-Lung 8}

The approval of afatinib for use in patients who have progressed on platinum-based chemotherapy was based on results from the open-label, Phase III LUX-Lung 8 study, which compared the second-line use of afatinib $(n=398)$ with erlotinib $(n=397)$ in patients with advanced squamous cell lung cancer. ${ }^{58}$ Median PFS was longer with afatinib compared with erlotinib (2.4 months [95\% $\mathrm{CI}=1.9-2.9]$ versus 1.9 months $[95 \% \mathrm{CI}=1.9-2.2]$; $\mathrm{HR}=0.82 \quad[95 \% \mathrm{CI}=0.68-1.00], P=0.0427)$, as was $\mathrm{OS}$ (median 7.9 months [95\% CI $=7.2-8.7]$ versus 6.8 months $[95 \% \quad \mathrm{CI}=5.9-7.8] ; \quad \mathrm{HR}=0.81 \quad[95 \% \quad \mathrm{CI}=0.69-0.95]$, $P=0.0077$; Figure 2). Although the proportion of patients with an objective response did not differ significantly between the treatment groups ( $6 \%$ versus $3 \%, P=0.055)$, the disease control rate was significantly higher in the afatinib group ( $51 \%$ versus $40 \%, P=0.002$ ).

Overall adverse event profiles were similar between the two treatment arms, with $57 \%$ of patients in each group experiencing a grade $\geq 3$ adverse event. However, afatinib was associated with higher incidence of grade $\geq 3$ treatment-related diarrhea $(10 \%$ versus $3 \%)$ and grade 3 stomatitis (4\% versus $0 \%)$ than erlotinib (Table 3). Overall, $27 \%$ of afatinib-treated patients and $14 \%$ of erlotinib-treated patients underwent dose reduction due to adverse events, and $20 \%$ and $17 \%$ of patients, respectively, discontinued treatment because of adverse events.

Data on patient-reported outcomes from LUX-Lung 8 suggest that the higher rate of adverse events with afatinib did not impact on symptom scores or quality of life, as assessed by the European Organization for Research and Treatment of Cancer Quality of Life Questionnaire C30 and its lung cancer-specific module, the QLQ-LC13. ${ }^{59}$ Moreover, significantly higher proportions of patients in the afatinib group than in the erlotinib group reported improved scores on the global health status/quality of life ( $36 \%$ versus $28 \%, P=0.041$ ), cough ( $43 \%$ versus $35 \%$, $P=0.029)$, and "dyspnea walked" scales $(35 \%$ versus $27 \%, P=0.022$ ); differences in the frequency of improvements in other scales, including pain ( $40 \%$ versus $39 \%)$ and dyspnea ( $51 \%$ versus $44 \%$ ), were not significant. Time to deterioration of dyspnea was significantly longer in afatinib-treated patients (median 2.6 versus 1.9 months, $P=0.008$ ).

Initial biomarker analyses using archival tissue from a subset of patients in LUX-Lung 8 indicated that the observed responses to afatinib were unlikely to be related to EGFR mutation or amplification. ${ }^{58}$ Additional analysis, conducted by Foundation Medicine (Cambridge, MA, USA) using next-generation sequencing, of a separate cohort of patients from LUX-Lung 8 that was enriched for patients with PFS $>2$ months indicated that these patients harbored a range of mutations, including TP53 (87\% of patients), LRP1B (39\%), KMT2D (33\%), CDKN2A (29\%) and FAT3 (26\%). ${ }^{32}$ Among the 245 patients undergoing molecular analysis, $22 \%$ had tumors with at least one $\operatorname{ErbB}$ family mutation, including a small proportion with mutations in more than one $\operatorname{ErbB}$ gene, and $7 \%$ of patients had at least one $E G F R$ mutation. In the afatinib arm, both PFS (median 4.9 versus 3.0 months, $P=0.06$ ) and $\mathrm{OS}$ (median 10.6 versus 8.1 months, $P=0.21$ ) were numerically longer in patients who had $\operatorname{ErbB}$ mutation-positive tumors $(\mathrm{n}=25)$ compared to those without ErbB mutations $(\mathrm{n}=107)$. In contrast, PFS and OS were similar in patients with $(\mathrm{n}=28)$ and without $(\mathrm{n}=85) \operatorname{ErbB}$ mutations in the erlotinib arm (median PFS: 2.7 versus 2.5 months, $P=0.29$; median OS: 7.2 versus 6.4 months, $P=0.46$ ). Interestingly, the enhanced benefit of afatinib over erlotinib in patients with $E r b B$ mutation-positive tumors appeared to be driven by mutations in HER3, 


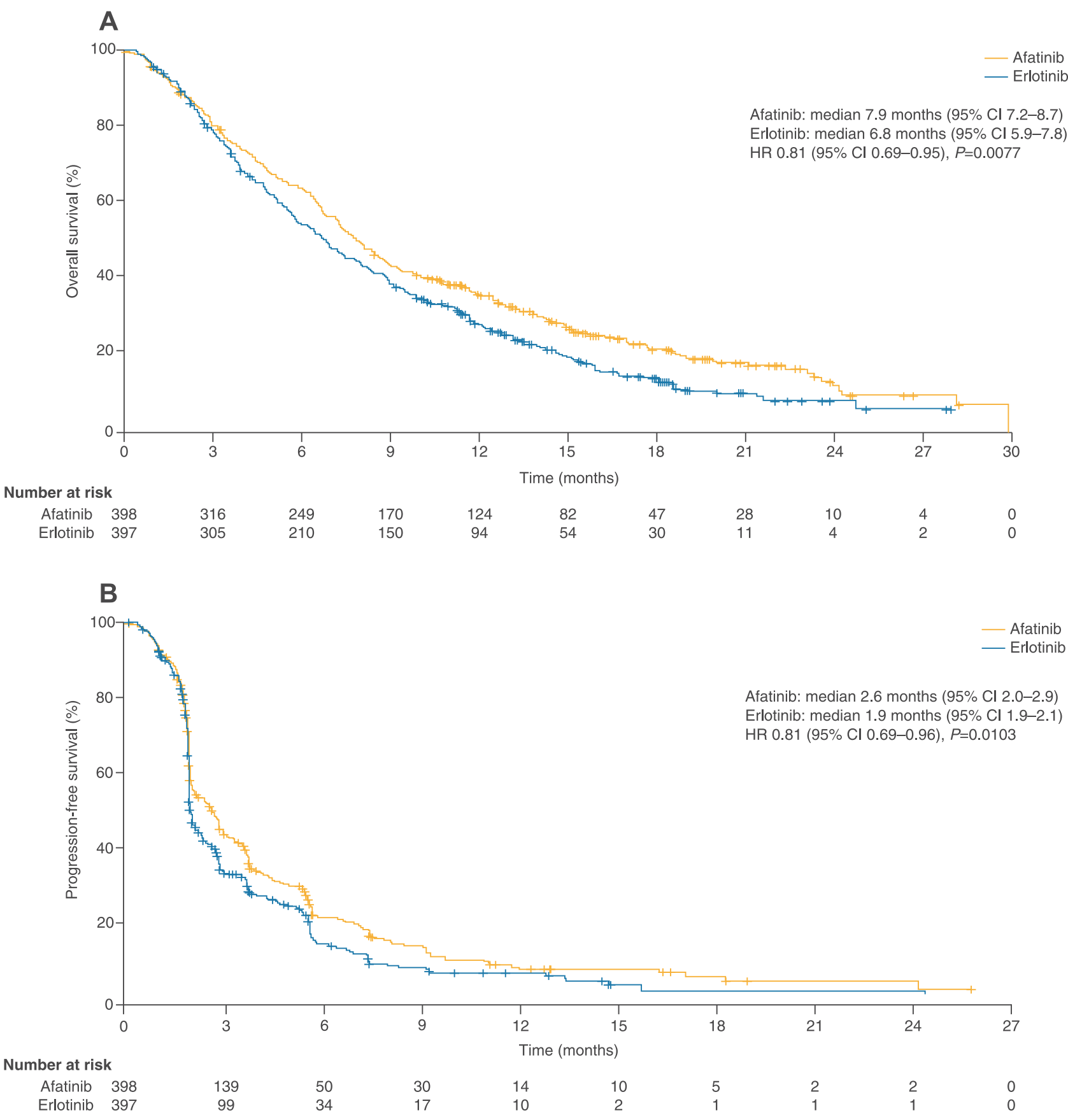

Figure 2 Progression-free (A) and overall (B) survival in the overall study population of LUX-Lung 8. - Reprinted from The Lancet Oncology, Vol I6, Soria JC, Felip E, Cobo $\mathrm{M}$, et al. Afatinib versus erlotinib as second-line treatment of patients with advanced squamous cell carcinoma of the lung (LUX-Lung 8): an open-label randomised controlled phase 3 trial, pp. 897-907, Copyright (2015), with permission from Elsevier. ${ }^{58}$

Abbreviations: $\mathrm{Cl}$, confidence interval; $\mathrm{HR}$, hazard ratio.

$H E R 4$, and, in particular, HER2, rather than EGFR. Among 12 patients with $H E R 2$-positive tumors, PFS $(\mathrm{HR}=0.06 \quad[95 \% \quad \mathrm{CI}=0.01-0.59], \quad P=0.02) \quad$ and $\mathrm{OS}$ $(\mathrm{HR}=0.06 \quad[95 \% \quad \mathrm{CI}=0.01-0.57], \quad P=0.02)$ significantly favored treatment with afatinib over erlotinib. In contrast, $E G F R$ overexpression did not predict PFS or OS benefit with afatinib over erlotinib.
Another retrospective analysis of LUX-Lung 8 was conducted using the VeriStrat ${ }^{\circledR}$ serum protein test. ${ }^{48}$ Among 412 (afatinib, $n=207$; erlotinib, $n=205$ ) patients classified as VS-G, OS was significantly longer with afatinib versus erlotinib (median 11.5 versus 8.9 months; $\mathrm{HR}=0.79$ [95\% CI=0.63-0.98], $P$ not reported]). In the VS-P group (afatinib, $\mathrm{n}=129$; erlotinib, $\mathrm{n}=134$ ), there 
Table 3 Most Common Treatment-Related Adverse Events Seen in LUX-Lung 8*.

\begin{tabular}{|c|c|c|c|c|c|c|c|c|}
\hline & \multicolumn{4}{|c|}{ Afatinib $(n=392)$} & \multicolumn{4}{|c|}{ Erlotinib $(n=395)$} \\
\hline & Grade I & Grade 2 & Grade 3 & Grade 4 & Grade I & Grade 2 & Grade 3 & Grade 4 \\
\hline Diarrhea & $165(42 \%)$ & $68(17 \%)$ & $39(10 \%)$ & $2(<1 \%)$ & 94 (24\%) & 28 (7\%) & $9(2 \%)$ & $\mathrm{I}(<1 \%)$ \\
\hline Rash or acne ${ }^{\dagger}$ & 157 (40\%) & $83(21 \%)$ & $23(6 \%)$ & $0(0 \%)$ & 142 (36\%) & $83(21 \%)$ & $41(10 \%)$ & $0(0 \%)$ \\
\hline Stomatitis ${ }^{\dagger}$ & 65 (17\%) & $32(8 \%)$ & $16(4 \%)$ & $0(0 \%)$ & 21 (5\%) & $13(3 \%)$ & $0(0 \%)$ & $0(0 \%)$ \\
\hline Fatigue $^{\dagger}$ & $33(8 \%)$ & $20(5 \%)$ & $6(2 \%)$ & $0(0 \%)$ & $24(6 \%)$ & $17(4 \%)$ & $7(2 \%)$ & $0(0 \%)$ \\
\hline Nausea & $35(9 \%)$ & $13(3 \%)$ & $4(1 \%)$ & $0(0 \%)$ & $20(5 \%)$ & $5(1 \%)$ & $3(<1 \%)$ & $0(0 \%)$ \\
\hline Decreased appetite & $31(8 \%)$ & $16(4 \%)$ & $3(<1 \%)$ & $0(0 \%)$ & $24(6 \%)$ & $15(4 \%)$ & $2(<1 \%)$ & $0(0 \%)$ \\
\hline Paronychia $^{\dagger}$ & $28(7 \%)$ & II (3\%) & $2(<1 \%)$ & $0(0 \%)$ & $9(2 \%)$ & $7(2 \%)$ & I (<1\%) & $0(0 \%)$ \\
\hline Dry skin & $28(7 \%)$ & $4(1 \%)$ & $2(<1 \%)$ & $0(0 \%)$ & $34(9 \%)$ & $7(2 \%)$ & $0(0 \%)$ & $0(0 \%)$ \\
\hline Pruritus & $22(6 \%)$ & $9(2 \%)$ & $\mathrm{I}(<1 \%)$ & $0(0 \%)$ & 37 (9\%) & $10(3 \%)$ & $0(0 \%)$ & $0(0 \%)$ \\
\hline Vomiting & $20(5 \%)$ & $8(2 \%)$ & $3(<1 \%)$ & $0(0 \%)$ & $7(2 \%)$ & $4(1 \%)$ & $2(<1 \%)$ & $0(0 \%)$ \\
\hline Dehydration & $2(<1 \%)$ & $5(1 \%)$ & $3(<1 \%)$ & $4(1 \%)$ & $0(0 \%)$ & $0(0 \%)$ & $3(<1 \%)$ & $0(0 \%)$ \\
\hline
\end{tabular}

Notes: *Includes grade 1-2 adverse events that occurred in $>10 \%$ of patients, or grade 3-5 adverse events that occurred in $>1 \%$ patients within any treatment group. ${ }^{\dagger}$ Grouped term. Reprinted from The Lancet Oncology, Vol 16, Soria JC, Felip E, Cobo M, et al. Afatinib versus erlotinib as second-line treatment of patients with advanced squamous cell carcinoma of the lung (LUX-Lung 8): an open-label randomised controlled phase 3 trial, pp. 897-907, Copyright (2015), with permission from Elsevier. ${ }^{58}$

was no significant difference in OS between afatinib and erlotinib (median 4.7 versus 4.8 months; HR=0.90 [95\% $\mathrm{CI}=0.70-1.16], P$ not reported). Multivariate analysis showed that VeriStrat ${ }^{\circledR}$ classification was an independent predictor of OS in afatinib-treated patients, regardless of ECOG performance status or best response to first-line therapy. Together, these findings suggest that certain groups of patients with squamous cell lung cancer, such as those with HER2 mutations and those classified as VS-G, may derive particular benefit from afatinib.

It is important to note that the LUX-Lung 8 study was performed when the first-line standard of care for unselected patients with squamous cell lung cancer was chemotherapy. The treatment landscape has markedly expanded since LUX-Lung 8 was conducted; most notably, immune checkpoint inhibitors with or without chemotherapy are now available as first- and second-line treatment options, and erlotinib would no longer be considered a relevant comparator for second-line treatment in a prospective clinical trial. Docetaxel in combination with ramucirumab is now an established second-line treatment; however, at present there are no prospective, clinical data comparing afatinib with docetaxel alone or in combination with ramucirumab.

\section{Safety of Afatinib and Use of the Tolerability-Guided Dose Modification Protocol}

Afatinib has an established, predictable, and manageable safety profile that is consistent with its mode of action. ${ }^{52,53}$ No new safety signals were observed in patients with squamous cell lung cancer in LUX-Lung 8, with diarrhea (all grades/grade $\geq 3: 70 / 10 \%$ ), rash/acne (67/6\%), and stomatitis (29/4\%) being the most common adverse events with afatinib (Table 3). ${ }^{58}$

Although afatinib can be associated with some severe treatment-related adverse events, following the established tolerability-guided dose modification protocol can help mitigate these reactions and allow patients to remain on treatment for as long as possible. ${ }^{53}$ According to this protocol, ${ }^{7}$ afatinib should be withheld for: any adverse reactions of grade $\geq 3$; diarrhea of grade 2 persisting for $\geq 2$ consecutive days while taking anti-diarrheal medication; cutaneous reactions of grade 2 that last $>7$ days or are intolerable. Treatment should be resumed at a reduced dose when the adverse reaction has fully resolved, improved to grade 1, or returned to baseline. Dosing should be reduced by $10 \mathrm{mg}$ decrements, to a minimum of $20 \mathrm{mg} /$ day. Results from several studies in patients with 
EGFR mutation-positive NSCLC have shown that dose reductions reduce the incidence and severity of treatmentrelated adverse events, without reducing the efficacy of afatinib. $^{60-62}$

Although dose reductions in LUX-Lung 8 occurred more frequently in patients treated with afatinib (27\%) than with erlotinib $(14 \%),{ }^{58}$ this may have been due to the availability of multiple dose formulations of afatinib and the clear dose modification guidelines in the accompanying prescribing information. ${ }^{7}$ The implementation of these guidelines may underlie the finding that similar proportions of patients in the afatinib and erlotinib groups discontinued treatment due to adverse events (20\% versus $17 \%$ ), despite the fact that more patients in the afatinib group than the erlotinib group experienced grade $\geq 3$ treatment-related adverse events (27\% versus 17\%) and/or required dose reductions. ${ }^{58}$

As noted previously, because the LUX-Lung 8 study was conducted before immunotherapy became the mainstay for the first-line treatment of advanced squamous cell lung cancer, there are no clinical trial data investigating the effect of prior immunotherapy on safety outcomes with afatinib.

\section{Evidence from Individual Patient Cases}

No additional clinical trial data on the use of afatinib as second-line treatment of advanced squamous cell lung cancer are available. As such, reports from the "real-world" clinical setting provide important information on treatment outcomes with second-line afatinib following chemotherapy or immunotherapy. In these settings, a number of patient case examples support the use of afatinib in patients with particular clinical characteristics, including $\operatorname{ErbB}$ family mutations. For example, afatinib given after chemotherapy, antiangiogenesis therapy, and icotinib successfully stabilized EGFR and HER2 mutation-positive squamous cell lung cancer in an elderly Chinese patient for at least 8 months, with no treatment-related adverse events. ${ }^{63}$ Further details have also been published of a patient enrolled in LUX-Lung 8, with multiple genetic aberrations, including $E G F R$ copy number amplification and mutations in ErbB4, ALK, RET and BRCA. This patient experienced prolonged PFS (14.7 months) and OS (17.7 months) with afatinib; ${ }^{64}$ of note, final analysis of LUX-Lung 8 has since identified 21 patients who remained on afatinib treatment for at least 12 months. ${ }^{65}$

Afatinib has also provided clinical benefit to patients without detectable genetic anomalies, including a patient who had received chemotherapy, radiotherapy, and radiosurgery, and subsequently developed hemoptysis following treatment with nivolumab. ${ }^{66}$ This patient, who had no detectable $E G F R$ or $A L K$ aberrations, experienced symptomatic relief from dysphonia shortly after commencing afatinib, with no obvious adverse effects. Afatinib was given to another elderly patient who had experienced disease progression and left lung atelectasis following first-line nab-paclitaxel, resulting in resolution of the atelectasis and shrinkage of the central tumor mass, with no adverse effects. ${ }^{67}$

\section{Where Does Afatinib Fit in the Squamous Cell Lung Cancer Treatment Paradigm?}

Personalized treatment based on validated predictive biomarkers as well as individual characteristics is nowadays the optimal approach for the treatment of NSCLC. Unfortunately, unlike for patients with adenocarcinoma NSCLC, to date, no predictive genomic biomarkers have been identified for NSCLC of squamous cell histology. Hence, cytotoxic chemotherapy and immune checkpoint inhibitors are the established "gold standard" for the firstline treatment of most patients with advanced squamous cell lung cancer, ${ }^{12,18}$ with the choice of regimen dependent on many factors, including the patient's age, performance status, and PD-L1 TPS. Following progression on first-line therapy, molecular and physical characteristics may preclude use of further chemotherapy, and alternative treatments will be required for some patients. Alternative options will also be required to treat patients for whom immunotherapy is contraindicated, such as those with autoimmune disease.

For certain patients who are not candidates for cytotoxic chemotherapy or immunotherapy and have a good performance status, afatinib may represent a convenient second- or third-line treatment option. The challenge for clinicians is identifying these patients in routine clinical practice, and further research into predictive biomarkers that can be easily applied in the clinic is clearly needed. The Veristrat ${ }^{\circledR}$ proteomic test has been validated and is covered by payors in the USA, including Medicare and Medicaid; the turnaround time is approximately 72 hours. As discussed above, having a patient with VS-G classification will give a level of comfort to physicians to treat the patient with an EGFR TKI over systemic chemotherapy. Moreover, evidence from patient case studies suggests that some unselected patients have experienced long-term benefit from afatinib, with minimal 
toxicity, suggesting that a trial may be worthwhile in patients who are not candidates for other therapies.

Until more data are available, afatinib could be considered a potential second- or third-line treatment option for some patients who are not eligible for other more established therapies. For example, as a second-line option for patients who have progressed on combined chemo-immunotherapy and who are ineligible for docetaxel plus ramucirumab, and as a third-line option in patients who have received first-line immunotherapy and second-line chemotherapy (e.g., docetaxel, gemcitabine or platinum-based chemotherapy) or chemotherapy and antiangiogenesis therapy (e.g. docetaxel plus ramucirumab). Due to the currently limited range of secondand third-line treatment options, investigating an agent with an entirely new mechanism of action is warranted, particularly in patients with physical or molecular characteristics that preclude the use of chemotherapy. Also, if available, molecular analysis to identify $\operatorname{ErbB}$ family mutations could help to further identify patients who may be likely to derive the most benefit from afatinib, in addition to Veristrat ${ }^{\circledR}$ profiling as previously discussed. Importantly however, further data are required to establish the optimal place for afatinib in the squamous cell lung cancer treatment landscape, specifically among the first- and second-line treatment options that have emerged in recent years.

Afatinib may also be of value for patients who find that intravenous administration of chemotherapy and immunotherapy is logistically problematic (for example, if there is a preference or need to restrict travel to the clinic for drug infusion), or substantially impacts on their quality of life. Studies suggest that oral therapies are generally preferred by patients, ${ }^{68,69}$ and may improve quality of life since oral drug administration is more convenient and flexible. ${ }^{68,70}$ Further, oral treatment eliminates the risks and discomfort associated with intravenous administration, such as phlebitis, pain, infection, bleeding, infusion reactions, and vascular damage, and frees up valuable healthcare resources. ${ }^{11,69-71}$

No cost-effectiveness data on the use of afatinib as second-line treatment of advanced squamous cell lung cancer in the US are currently available, and further data are required in this respect. However, analyses of the LUX-Lung 8 study, undertaken from the perspective of patients treated in France and China, suggest that afatinib may be cost-effective in those countries. ${ }^{72,73}$ The French analysis calculated a $97 \%$ probability of afatinib being cost-effective, assuming a willingness-to-pay threshold of EUR70,000 per quality-adjusted life year gained. ${ }^{72}$

\section{The Future of Squamous Cell Lung Cancer Therapy}

A number of trials are ongoing or recently completed that may offer further options for patients with squamous cell lung cancer. Results from the Phase III CHECKMATE-227 study enrolling chemotherapy-naïve patients with stage IV NSCLC have led to nivolumab plus the anti-cytotoxic T-lymphocyte-antigen (CTLA) 4 monoclonal antibody, ipilimumab, being recently approved by the FDA as a first-line treatment option for patients with $\mathrm{PD}-\mathrm{L} 1 \geq 1 \%$. In the most recent analysis, nivolumab plus ipilimumab was shown to prolong median OS relative to platinum-based chemotherapy in patients with $\mathrm{PD}-\mathrm{L} 1$ expression $\geq 1 \%$ (17.1 versus 14.9 months, $P=0.007)$ and in patients with PD-L1 $<1 \%(17.2$ versus 12.2 months, $P$ not reported). ${ }^{13-15}$ Nivolumab in combination with chemotherapy, however, did not prolong survival relative to chemotherapy alone. ${ }^{74}$

In the second-line setting in patients with squamous cell lung carcinoma, the ipilimumab plus nivolumab combination does not appear to offer any advantages over nivolumab alone. Results from a non-biomarker-matched substudy of the Phase III Lung-MAP umbrella trial showed that adding ipilimumab to nivolumab in previously treated but immunotherapy-naïve patients with advanced squamous cell lung carcinoma with any PD-L1 level did not enhance survival. ${ }^{75}$ Further findings from the biomarker-driven Lung-MAP study, which is currently investigating a number of different targeted therapies in NSCLC, including durvalumab plus tremelimumab and rucaparib, may further advance the use of personalized therapy in squamous cell lung carcinoma. ${ }^{12,76}$

Results from the Phase III IMpower110 study, enrolling chemotherapy-naïve patients with stage IV NSCLC, has led to recent FDA approval of atezolizumab monotherapy as a first-line treatment option for patients with high PD-L1 expression. Atezolizumab monotherapy was shown to significantly prolong median OS relative to platinum-based chemotherapy in patients with high PD-L1 expression (20.2 versus 13.1 months, $P=0.0106$ ). Primary analysis of the Phase III IMpower131 study suggested that the addition of atezolizumab to platinum-based chemotherapy in the first-line treatment of advanced squamous cell lung cancer prolonged survival. ${ }^{77}$ Median PFS with atezolizumab plus chemotherapy was 6.3 months compared with 5.6 months in patients receiving chemotherapy alone $\quad(\mathrm{HR}=0.71 \quad[95 \% \quad \mathrm{CI}=0.60-0.85], \quad P=0.0001){ }^{77}$ 
However, final OS analysis suggested that the addition of atezolizumab only prolongs OS in patients with high PDL1 levels, with median OS of 14.2 months in patients receiving chemotherapy plus atezolizumab compared with 13.5 months $\quad(\mathrm{HR}=0.88 \quad[95 \% \quad \mathrm{CI}=0.73-1.05]$; $P=0.158$ ) for chemotherapy alone in the intention to treat populations, and 23.4 versus 10.2 months $(\mathrm{HR}=0.48$ [95\% $\mathrm{CI}=0.29-0.81]$; $P$ not formally calculated) in the PD-L1high population. ${ }^{77}$ No differences in median OS were seen between the treatment arms in the overall PD-L1-positive population (14.8 versus 15.0 months), or in PD-L1negative patients (median 14.0 versus 12.5 months). ${ }^{77}$

Early-phase studies are also exploring various combinations of approved and investigational agents, including pembrolizumab plus ramucirumab, ${ }^{78}$ and novel agents such as anlotinib ${ }^{79}$ and camrelizumab. ${ }^{80}$

It has been suggested that radiotherapy in addition to chemotherapy plus immune checkpoint inhibitors, the current first-line standard of care for patients with advanced NSCLC, may further improve outcomes, but this strategy is yet to be tested in clinical trials. ${ }^{81}$

Compared with afatinib monotherapy, afatinib combination therapy with other agents may yield better efficacy results in general EGFR wild-type populations. The Phase II, single-arm LUX-Lung IO/KEYNOTE-497 is investigating the efficacy of afatinib plus pembrolizumab in unselected patients with locally advanced/metastatic squamous cell lung carcinoma that has progressed during or after first-line platinum-based chemotherapy. ${ }^{82}$ Enrollment for this study has closed, but no results are available as yet.

\section{Conclusions}

Agents such as chemotherapy and immune checkpoint inhibitors appear to be the most efficacious therapies across a broad range of patients with squamous cell lung carcinoma when used early in the disease course. Further data are required to establish the optimal place for afatinib within the squamous cell lung cancer treatment landscape. However, until further data are available afatinib may be considered an option for some patients who have progressed on previous therapies but are not eligible for existing, more-established therapies.

Afatinib may be a particularly good second- or third-line option in certain problematic clinical scenarios. When immunotherapy is used alone or in combination with chemotherapy as first-line treatment, the findings from CheckMate 017 (nivolumab versus docetaxel in unselected patients with progressive disease after first-line platinum-based chemotherapy) ${ }^{23}$ and OAK (atezolizumab versus docetaxel in unselected patients with progressive disease after one or two previous chemotherapy regimens) ${ }^{24}$ studies cannot be applied. In addition, if the patient was initially treated with pembrolizumab, Keynote-001 (pembrolizumab in patients with treatment failure after prior systemic therapy ${ }^{83}$ ) and Keynote-010 (pembrolizumab versus docetaxel in patients with PD-L1 TPS $\geq 1 \%$ and progressive disease after platinum-containing chemotherapy ${ }^{84}$ ) are also not applicable.

These limitations leave only four options as second- or subsequent-line treatment for many patients. These are docetaxel plus ramucirumab, afatinib, gemcitabine as a single agent or as one of several available platinum-doublet chemotherapy options, and participation in a clinical trial. The REVEL trial showed that the combination of docetaxel and ramucirumab was superior to docetaxel alone, ${ }^{22}$ suggesting that docetaxel monotherapy is no longer appropriate unless the patient cannot receive ramucirumab. As ramucirumab was not studied in patients with centrally-located tumors or cavitation, docetaxel in combination with ramucirumab may not be appropriate in such scenarios. ${ }^{22,85}$

The second option, oral afatinib monotherapy, has been shown to confer an OS benefit over erlotinib in patients with squamous cell lung cancer. ${ }^{58}$ Although erlotinib is no longer approved in this indication, and direct comparisons cannot be made with other agents, the OS seen in patients who progressed after platinum-based chemotherapy with afatinib (7.9 months) is comparable to that seen with docetaxel (8.2 months) in the REVEL study in the secondline setting. ${ }^{22}$ Notably, both the REVEL and LUX-Lung 8 studies were conducted before the immunotherapy era. Recent data among patients with EGFR mutation-positive NSCLC suggesting that the use of afatinib following antiPD-(L)1 therapy is not associated with severe immunerelated adverse events ${ }^{86}$ are reassuring, and support further investigation of afatinib in patients who have previously received immune checkpoint inhibitors.

The third option is gemcitabine therapy; however, the data supporting its use as a single agent in the second-line setting come primarily from Phase II studies. ${ }^{87-89}$ Certainly, the use of platinum-based doublets incorporating gemcitabine in chemotherapy-naïve NSCLC patients is well established, with comparable efficacy to other platinum-based combinations. ${ }^{90}$ Gemcitabine monotherapy may also be useful in the maintenance setting. In a Phase III study, gemcitabine or erlotinib maintenance was compared with observation alone in patients whose disease was controlled 
after cisplatin-gemcitabine induction chemotherapy. ${ }^{91}$ This study demonstrated that maintenance therapy with erlotinib (switch) or gemcitabine (continuation) significantly delayed disease progression after cisplatin-gemcitabine induction.

In summary, afatinib monotherapy may be a suitable therapeutic option for some patients with squamous cell lung cancer in the second- or third-line setting, but further assessment of the optimal place of afatinib within the current treatment landscape is required. Further, biomarker analyses and a small number of case studies suggest that certain groups of patients, such as those harboring mutations in the $E r b B$ family of receptor tyrosine kinases, may derive particular benefit from afatinib. Further studies should help to determine whether efficacy can be improved by the addition of other agents such as pembrolizumab.

\section{Abbreviations}

ALK, anaplastic lymphoma kinase; CI, confidence interval; Del19, deletion in exon 19 of the EGFR gene; ECOG, Eastern Cooperative Oncology Group; EGFR, epidermal growth factor receptor; FDA, Food and Drug Administration; HER2, human epidermal growth factor receptor; HR, hazard ratio; NLM, National Library of Medicine; NSCLC, non-small-cell lung cancer; NTRK, neurotrophic receptor tyrosine kinase; OS, overall survival; PD-L1, programmed death-ligand 1; PFS, progression-free survival; SCC, squamous cell carcinoma; TKI, tyrosine kinase inhibitor; TMB, tumor mutational burden; TPS, tumor proportion score; US, United States.

\section{Acknowledgments}

The author(s) meet criteria for authorship as recommended by the International Committee of Medical Journal Editors (ICMJE). The authors received no direct compensation related to the development of the Manuscript. Writing, editorial support and formatting assistance was provided by Natalie Grainger and Laura Winton, of GeoMed, an Ashfield company, part of UDG Healthcare plc, which was contracted and funded by Boehringer Ingelheim Pharmaceuticals, Inc. (BIPI). BIPI was given the opportunity to review the Manuscript for medical and scientific accuracy as well as intellectual property considerations.

\section{Disclosure}

ES reports speaker's bureau fees from Genentech, Astellas, Amgen, Biodesix, Paradigm Diagnostic, Boehringer-Ingelheim, Caris SL, Celgene, Guardant Health, Pfizer, AstraZeneca, Novartis, Merck, Takeda,
Sanofi Genzyme, and Dova. He is also consultants for Lilly US Oncology, BluePrint Medicine and Inivata. LH reports grant/research support from Boehringer-Ingelheim, Genentech, Merck, and BMS, consultancy fees from Genentech and Merck, and speaker's bureau fees from Genentech and Boehringer Ingelheim. LH also reports he has previously received speaker's bureau and/or consulting fees from Novartis and Eli Lilly. He was part of the advisory boards and consultant for G1 Therapeutics. The authors report no other conflicts of interest in this work.

\section{References}

1. National Institute of Health (National Cancer Institute). Non-small cell lung cancer treatment $\left(\mathrm{PDQ}^{\circledR}\right)$-health professional version; 2019. [Updated 06, 2019]. Available from: https://www.cancer.gov/types/ lung/hp/non-small-cell-lung-treatment-pdq\#cit/section_2.1. Accessed December 1, 2019.

2. Schwaederle M, Elkin SK, Tomson BN, Carter JL, Kurzrock R. Squamousness: next-generation sequencing reveals shared molecular features across squamous tumor types. Cell Cycle. 2015;14 (14):2355-2361. doi:10.1080/15384101.2015.1053669

3. Friedlaender A, Banna G, Malapelle U, Pisapia P, Addeo A. Next generation sequencing and genetic alterations in squamous cell lung carcinoma: where are we today? Front Oncol. 2019;9:166. doi:10.3389/fonc. 2019.00166

4. Cancer Genome Atlas Research Network. Comprehensive genomic characterization of squamous cell lung cancers. Nature. 2012;489 (7417):519-525. doi:10.1038/nature11404

5. Choi M, Kadara H, Zhang J, et al. Mutation profiles in early-stage lung squamous cell carcinoma with clinical follow-up and correlation with markers of immune function. Ann Oncol. 2017;28(1):83-89. doi:10.1093/annonc/mdw437

6. Testa U, Castelli G, Pelosi E. Lung cancers: molecular characterization, clonal heterogeneity and evolution, and cancer stem cells. Cancers (Basel). 2018;10(8):248. doi:10.3390/cancers10080248

7. Boehringer Ingelheim Pharmaceuticals I. GILOTRIF (afatinib) tablets: prescribing information. Revised October, 2019.

8. Lam VK, Tran HT, Banks KC, et al. Targeted tissue and cell-free tumor DNA sequencing of advanced lung squamous-cell carcinoma reveals clinically significant prevalence of actionable alterations. Clin Lung Cancer. 2019;20(1):30-36 e33. doi:10.1016/j.cllc.2018.08.020

9. Dearden S, Stevens J, Wu YL, Blowers D. Mutation incidence and coincidence in non small-cell lung cancer: meta-analyses by ethnicity and histology (mutMap). Ann Oncol. 2013;24(9):2371-2376. doi:10.1093/annonc/mdt205

10. Merck \& Co. Inc. Keytruda ${ }^{\circledR}$ (pembrolizumab) prescribing information. Revised September, 2019.

11. Mok TSK, Wu YL, Kudaba I, et al. Pembrolizumab versus chemotherapy for previously untreated, PD-L1-expressing, locally advanced or metastatic non-small-cell lung cancer (KEYNOTE-042): a randomised, open-label, controlled, Phase 3 trial. Lancet. 2019;393 (10183):1819-1830. doi:10.1016/S0140-6736(18)32409-7

12. Paik PK, Pillai RN, Lathan CS, Velasco SA, Papadimitrakopoulou V. New treatment options in advanced squamous cell lung cancer. $A m$ Soc Clin Oncol Educ Book. 2019;39(39):e198-e206. doi:10.1200/ EDBK_237829

13. Peters S, Ramalingam SS, Paz-Ares L, et al. Nivolumab (NIVO) + low-dose ipilimumab (IPI) vs platinum-doublet chemotherapy (CHEMO) as first-line (1L) Treatment (TX) for advanced non-small cell lung cancer (NSCLC): checkmate 227 part 1 final analysis. Ann Oncol. 2019;30(Suppl 5):v851-v934. doi:10.1093/annonc/mdz394.075 
14. FDA. FDA approves nivolumab plus ipilimumab for first-line mNSCLC (PD-L1Keytruda ${ }^{\circledR}$ (pembrolizumab) prescribing information tumor expression $\geq 1 \%$ ); 2020. Available from: https://www.fda. gov/drugs/drug-approvals-and-databases/fda-approves-nivolumabplus-ipilimumab-first-line-mnsclc-pd-11-tumor-expression-1. Accessed August 26, 2020.

15. Hellmann MD, Paz-Ares L, Bernabe Caro R, et al. Nivolumab plus ipilimumab in advanced non-small-cell lung cancer. $N$ Engl J Med. 2019;381(21):2020-2031. doi:10.1056/NEJMoa1910231

16. Spigel D, de Marinis F, Giaccone G, et al. Impower110: interim overall survival (OS) analysis of a phase III study of atezolizumab (ATEZO) VS platinum-based chemotherapy (CHEMO) as first-line (1L) treatment (TX) in PD-L1-selected NSCLC. Ann Oncol. 2019;30 (Suppl 5):v851-v934. doi:10.1093/annonc/mdz293

17. FDA. FDA approves atezolizumab for first-line treatment of metastatic NSCLC with high PD-L1 expression; 2020. Available from: https://www.fda.gov/drugs/resources-information-approved-drugs /fda-approves-atezolizumab-first-line-treatment-metastatic-nsclc-high -pd-11-expression. Accessed July 16, 2020.

18. Hanna N, Johnson D, Temin S, et al. Systemic therapy for stage IV non-small-cell lung cancer: American Society of Clinical Oncology Clinical Practice Guideline Update. J Clin Oncol. 2017;35 (30):3484-3515. doi:10.1200/JCO.2017.74.6065

19. FDA. OPDIVO (nivolumab) injection, for intravenous use Prescribing information; 2015. Availabe from: https://www.access data.fda.gov/drugsatfda_docs/label/2015/125527s000lbl.pdf. Accessed August 26, 2020.

20. FDA. TECENTRIQ ${ }^{\circledR}$ (atezolizumab) injection, for intravenous use. Prescribing information; 2019. Availabe from: https://www.access data.fda.gov/drugsatfda_docs/label/2019/761034s021lbl.pdf. Accessed August 26, 2020.

21. FDA. KEYTRUDA ${ }^{\circledR}$ (pembrolizumab) injection, for intravenous use. Prescribing information; 2020. Available from: https://www.access d a t a.fda.gov/drugs a t fda_docs/1 a b e $1 / 2020 /$ 125514s059s064s076s083lbl.pdf. Accessed August 26, 2020.

22. Garon EB, Ciuleanu TE, Arrieta O, et al. Ramucirumab plus docetaxel versus placebo plus docetaxel for second-line treatment of stage IV non-small-cell lung cancer after disease progression on platinum-based therapy (REVEL): a multicentre, double-blind, randomised phase 3 trial. Lancet. 2014;384(9944):665-673. doi:10.1016/S0140-6736(14)60845-X

23. Brahmer J, Reckamp KL, Baas P, et al. Nivolumab versus docetaxel in advanced squamous-cell non-small-cell lung cancer. $N$ Engl J Med. 2015;373(2):123-135. doi:10.1056/NEJMoa1504627

24. Rittmeyer A, Barlesi F, Waterkamp D, et al. Atezolizumab versus docetaxel in patients with previously treated non-small-cell lung cancer (OAK): a phase 3, open-label, multicentre randomised controlled trial. Lancet. 2017;389(10066):255-265. doi:10.1016/S01406736(16)32517-X

25. Roskoski RJr. The ErbB/HER family of protein-tyrosine kinases and cancer. Pharmacol Res. 2014;79:34-74. doi:10.1016/j.phrs.2013.11.002

26. Hirsch FR, Varella-Garcia M, Bunn PA Jr, et al. Epidermal growth factor receptor in non-small-cell lung carcinomas: correlation between gene copy number and protein expression and impact on prognosis. J Clin Oncol. 2003;21(20):3798-3807. doi:10.1200/ JCO.2003.11.069

27. Lee Y, Shim HS, Park MS, et al. High EGFR gene copy number and skin rash as predictive markers for EGFR tyrosine kinase inhibitors in patients with advanced squamous cell lung carcinoma. Clin Cancer Res. 2012;18(6):1760-1768. doi:10.1158/1078-0432.CCR-11-2582

28. Ugocsai K, Mandoky L, Tiszlavicz L, Molnar J. Investigation of HER2 overexpression in non-small cell lung cancer. Anticancer Res. 2005;25(4):3061-3066.

29. Heinmoller P, Gross C, Beyser K, et al. HER2 status in non-small cell lung cancer: results from patient screening for enrollment to a phase II study of herceptin. Clin Cancer Res. 2003;9(14):5238-5243.
30. Hirsch FR, Franklin WA, Veve R, Varella-Garcia M, Bunn PA Jr. HER2/neu expression in malignant lung tumors. Semin Oncol. 2002;29(1 Suppl 4):51-58. doi:10.1053/sonc.2002.31523

31. Yi ES, Harclerode D, Gondo M, et al. High c-erbB-3 protein expression is associated with shorter survival in advanced non-small cell lung carcinomas. Mod Pathol. 1997;10(2):142-148.

32. Goss GD, Felip E, Cobo M, et al. Association of ERBB mutations with clinical outcomes of afatinib- or erlotinib-treated patients with lung squamous cell carcinoma: secondary analysis of the LUX-lung 8 randomized clinical trial. JAMA Oncol. 2018;4(9):1189-1197. doi:10.1001/jamaoncol.2018.0775

33. Thatcher N, Hirsch FR, Luft AV, et al. Necitumumab plus gemcitabine and cisplatin versus gemcitabine and cisplatin alone as first-line therapy in patients with stage IV squamous non-small-cell lung cancer (SQUIRE): an open-label, randomised, controlled phase 3 trial. Lancet Oncol. 2015;16(7):763-774. doi:10.1016/S1470-2045(15)00021-2

34. Pirker R, Pereira JR, Szczesna A, et al. Cetuximab plus chemotherapy in patients with advanced non-small-cell lung cancer (FLEX): an open-label randomised phase III trial. Lancet. 2009;373 (9674):1525-1531. doi:10.1016/S0140-6736(09)60569-9

35. Lynch TJ, Patel T, Dreisbach L, et al. Cetuximab and first-line taxane/ carboplatin chemotherapy in advanced non-small-cell lung cancer: results of the randomized multicenter phase III trial BMS099. J Clin Oncol. 2010;28(6):911-917. doi:10.1200/JCO.2009.21.9618

36. Bonomi PD, Gandara D, Hirsch FR, et al. Predictive biomarkers for response to EGFR-directed monoclonal antibodies for advanced squamous cell lung cancer. Ann Oncol. 2018;29(8):1701-1709. doi:10.1093/annonc/mdy196

37. Genova C, Socinski MA, Hozak RR, et al. EGFR gene copy number by FISH may predict outcome of necitumumab in squamous lung carcinomas: analysis from the SQUIRE Study. J Thorac Oncol. 2018;13(2):228-236. doi:10.1016/j.jtho.2017.11.109

38. Herbst RS, Redman MW, Kim ES, et al. Cetuximab plus carboplatin and paclitaxel with or without bevacizumab versus carboplatin and paclitaxel with or without bevacizumab in advanced NSCLC (SWOG S0819): a randomised, phase 3 study. Lancet Oncol. 2018;19 (1):101-114. doi:10.1016/S1470-2045(17)30694-0

39. Paz-Ares L, Socinski MA, Shahidi J, et al. Correlation of EGFR-expression with safety and efficacy outcomes in SQUIRE: a randomized, multicenter, open-label, phase III study of gemcitabine-cisplatin plus necitumumab versus gemcitabine-cisplatin alone in the first-line treatment of patients with stage IV squamous non-small-cell lung cancer. Ann Oncol. 2016;27(8):1573-1579. doi:10.1093/annonc/mdw214

40. Gatzemeier U, Pluzanska A, Szczesna A, et al. Phase III study of erlotinib in combination with cisplatin and gemcitabine in advanced non-small-cell lung cancer: the tarceva lung cancer investigation trial. J Clin Oncol. 2007;25(12):1545-1552. doi:10.1200/JCO.2005.05.1474

41. Herbst RS, Giaccone G, Schiller JH, et al. Gefitinib in combination with paclitaxel and carboplatin in advanced non-small-cell lung cancer: a phase III trial-INTACT 2. J Clin Oncol. 2004;22(5):785-794. doi:10.1200/JCO.2004.07.215

42. Herbst RS, Prager D, Hermann R, et al. TRIBUTE: a phase III trial of erlotinib hydrochloride (OSI-774) combined with carboplatin and paclitaxel chemotherapy in advanced non-small-cell lung cancer. J Clin Oncol. 2005;23(25):5892-5899. doi:10.1200/JCO.2005.02.840

43. Gridelli C, Ciardiello F, Gallo C, et al. First-line erlotinib followed by second-line cisplatin-gemcitabine chemotherapy in advanced non-small-cell lung cancer: the TORCH randomized trial. J Clin Oncol. 2012;30(24):3002-3011. doi:10.1200/JCO.2011.41.2056

44. Clark GM, Zborowski DM, Santabarbara P, et al. Smoking history and epidermal growth factor receptor expression as predictors of survival benefit from erlotinib for patients with non-small-cell lung cancer in the National Cancer Institute of Canada Clinical Trials Group study BR.21. Clin Lung Cancer. 2006;7(6):389-394. doi:10.3816/CLC.2006.n.022 
45. Leon L, Lee G. Efficacy and safety of erlotinib in non-small cell lung cancer of squamous cell and adenocarcinoma histology in the phase 3 NCIC CTG BR.21 and SATURN (BO18192) trials. 37th European Society for Medical Oncology (ESMO) Congress; September 28October 2; 2012; Vienna, Austria; Poster 1277P.

46. Garassino MC, Martelli O, Broggini M, et al. Erlotinib versus docetaxel as second-line treatment of patients with advanced non-smallcell lung cancer and wild-type EGFR tumours (TAILOR): a randomised controlled trial. Lancet Oncol. 2013;14(10):981-988. doi:10.1016/S1470-2045(13)70310-3

47. Gregorc V, Novello S, Lazzari C, et al. Predictive value of a proteomic signature in patients with non-small-cell lung cancer treated with second-line erlotinib or chemotherapy (PROSE): a biomarker-stratified, randomised phase 3 trial. Lancet Oncol. 2014;15(7):713-721. doi:10.1016/S1470-2045(14)70162-7

48. Gadgeel S, Goss G, Soria JC, et al. Evaluation of the VeriStrat((R)) serum protein test in patients with advanced squamous cell carcinoma of the lung treated with second-line afatinib or erlotinib in the phase III LUX-lung 8 study. Lung Cancer. 2017;109:101-108. doi:10.1016/ j.lungcan.2017.05.010

49. Peters S, Stahel RA, Dafni U, et al. Randomized phase III trial of erlotinib versus docetaxel in patients with advanced squamous cell non-small cell lung cancer failing first-line platinum-based doublet chemotherapy stratified by VeriStrat good versus VeriStrat poor. The European Thoracic Oncology Platform (ETOP) EMPHASIS-lung trial. J Thorac Oncol. 2017;12(4):752-762. doi:10.1016/j.jtho.2016.12.017

50. Solca F, Dahl G, Zoephel A, et al. Target binding properties and cellular activity of afatinib (BIBW 2992), an irreversible ErbB family blocker. J Pharmacol Exp Ther. 2012;343(2):342-350. doi:10.1124/ jpet.112.197756

51. Kohsaka S, Nagano M, Ueno T, et al. A method of high-throughput functional evaluation of EGFR gene variants of unknown significance in cancer. Sci Transl Med. 2017;9(416). doi:10.1126/scitranslmed.aan6566

52. Wu YL, Zhou C, Hu CP, et al. Afatinib versus cisplatin plus gemcitabine for first-line treatment of Asian patients with advanced non-small-cell lung cancer harbouring EGFR mutations (LUX-lung 6): an open-label, randomised phase 3 trial. Lancet Oncol. 2014;15(2):213-222. doi:10.1016/S1470-2045(13)70604-1

53. Sequist LV, Yang JC, Yamamoto N, et al. Phase III study of afatinib or cisplatin plus pemetrexed in patients with metastatic lung adenocarcinoma with EGFR mutations. J Clin Oncol. 2013;31 (27):3327-3334. doi:10.1200/JCO.2012.44.2806

54. Yang JC, Wu YL, Schuler M, et al. Afatinib versus cisplatin-based chemotherapy for EGFR mutation-positive lung adenocarcinoma (LUX-lung 3 and LUX-lung 6): analysis of overall survival data from two randomised, phase 3 trials. Lancet Oncol. 2015;16 (2):141-151. doi:10.1016/S1470-2045(14)71173-8

55. Park K, Tan EH, O’Byrne K, et al. Afatinib versus gefitinib as first-line treatment of patients with EGFR mutation-positive non-small-cell lung cancer (LUX-lung 7): a phase 2B, open-label, randomised controlled trial. Lancet Oncol. 2016;17(5):577-589. doi:10.1016/S1470-2045(16)30033-X

56. National Comprehensive Cancer Network. Referenced with permission from the NCCN Clinical Practice Guidelines in Oncology (NCCN Guidelines ${ }^{\circledR}$ ) for Non Small Cell Lung Cancer V.6.2020. (C) National Comprehensive Cancer Network, Inc 2020. All rights reserved. Accessed June 23, 2020. To view the most recent and complete version of the guideline, go online to NCCN.org. NCCN makes no warranties of any kind whatsoever regarding their content, use or application and disclaims any responsibility for their application or use in any way.

57. Planchard D, Popat S, Kerr K, et al. Metastatic non-small-cell lung cancer: ESMO clinical practice guidelines for diagnosis, treatment and follow-up. Ann Oncol. 2018;29(Supp14):iv192-iv237. doi:10.1093/annonc/mdy275
58. Soria JC, Felip E, Cobo M, et al. Afatinib versus erlotinib as second-line treatment of patients with advanced squamous cell carcinoma of the lung (LUX-Lung 8): an open-label randomised controlled phase 3 trial. Lancet Oncol. 2015;16(8):897-907. doi:10.1016/S1470-2045(15)00006-6

59. Felip E, Hirsh V, Popat S, et al. Symptom and quality of life improvement in LUX-lung 8, an open-label phase III study of second-line afatinib versus erlotinib in patients with advanced squamous cell carcinoma of the lung after first-line platinum-based chemotherapy. Clin Lung Cancer. 2018;19(1):74-83 e11. doi:10.1016/j.cllc.2017.06.002

60. Schuler M, Tan EH, O'Byrne K, et al. First-line afatinib vs gefitinib for patients with EGFR mutation-positive NSCLC (LUX-lung 7): impact of afatinib dose adjustment and analysis of mode of initial progression for patients who continued treatment beyond progression. $J$ Cancer Res Clin Oncol. 2019;145(6):1569-1579. doi:10.1007/ s00432-019-02862-x

61. Halmos B, Tan EH, Soo RA, et al. Impact of afatinib dose modification on safety and effectiveness in patients with EGFR mutation-positive advanced NSCLC: results from a global real-world study (RealGiDo). Lung Cancer. 2019;127:103-111. doi:10.1016/j.lungcan.2018.10.028

62. Yang JC, Sequist LV, Zhou C, et al. Effect of dose adjustment on the safety and efficacy of afatinib for EGFR mutation-positive lung adenocarcinoma: post hoc analyses of the randomized LUX-lung 3 and 6 trials. Ann Oncol. 2016;27(11):2103-2110. doi:10.1093/ annonc/mdw322

63. Gao Y, Zheng A, Zhu X, Song J, Xue Q. Clinical benefit from afatinib in an advanced squamous cell lung carcinoma patient harboring HER2 S310Y mutation: a case report. Onco Targets Ther. 2018;11:8705-8710. doi:10.2147/OTT.S182812

64. Jian H, Han Y, Yu Y, Lu S. Long-term efficacy of afatinib in a patient with squamous cell carcinoma of the lung and multiple ERBB family aberrations: afatinib in ERBB+ lung squamous cell carcinoma. Anticancer Drugs. 2019;30(8):873-878. doi:10.1097/ CAD. 0000000000000813

65. Goss GDCM, Lu S, Syrigos K, et al. Afatinib versus erlotinib as second-line treatment of patients (pts) with advanced lung squamous cell carcinoma (SCC): final analysis of the global phase III LUX-lung 8 (LL8) trial. 2018; European Society of Medical Oncology congress; October 19-23; 2018; Munich, Germany; Poster 4178.

66. Jin Y, Jiang Q, Xin T. Afatinib treatment of a squamous lung cancer after tumor progression of nivolumab. Thorac Cancer. 2018;9 (1):164-166. doi:10.1111/1759-7714.12522

67. Hohenforst-Schmidt W, Zarogoulidis P, Steinheimer M, et al. Second-line afatinib administration in an elderly patient with squamous cell carcinoma. Ther Clin Risk Manag. 2017;13:341-343. doi:10.2147/TCRM.S130816

68. Eek D, Krohe M, Mazar I, et al. Patient-reported preferences for oral versus intravenous administration for the treatment of cancer: a review of the literature. Patient Prefer Adherence. 2016;10:1609-1621. doi:10.2147/PPA.S106629

69. Borner M, Scheithauer W, Twelves C, Maroun J, Wilke H. Answering patients' needs: oral alternatives to intravenous therapy. Oncologist. 2001;Suppl 4:12-16. doi:10.1634/theoncologist.6-suppl_4-12

70. Mahay H. Oral chemotherapy: patient advantages and challenges. Pharm Times. 2009;75:64-65.

71. Sait MK, Aguam AP, Mohidin S, et al. Intravenous site complications for patients receiving chemotherapy: an observational study. Ann Short Rep. 2019;2:1032.

72. Pignata M, Chouaid C, Le Lay K, et al. Evaluating the cost-effectiveness of afatinib after platinum-based therapy for the treatment of squamous non-small-cell lung cancer in France. Clinicoecon Outcomes Res. 2017;9:655-668. doi:10.2147/CEOR.S136657 
73. Zhu J, He W, Ye M, et al. Cost-effectiveness of afatinib and erlotinib as second-line treatments for advanced squamous cell carcinoma of the lung. Future Oncol. 2018;14(27):2833-2840. doi:10.2217/fon-2018-0321

74. Bristol-Myers Squibb Company. Bristol-Myers Squibb provides update on part 2 of CheckMate -227: study did not meet its primary endpoint of overall survival with Opdivo ${ }^{\circledR}$ (nivolumab) plus chemotherapy vs. chemotherapy in first-line non-squamous non-small cell lung cancer (released 24 July, 2019). [press release]. Availabe from: https://news bms.com/press-release/rd-news/bristol-myers-squibb-provides-updatepart-2-checkmate-227. Accessed October 18, 2019.

75. Bazhenova L, Redman M, Gettinger S, et al. OA04.01 A phase III randomized study of nivolumab/ipilumumab vs nivolumab for previously-treated stage IV squamous cell lung cancer. IASCLC 2019 World Conference on Lung Cancer September 7-10; 2019, Barcelona, Spain. [abstract].

76. Herbst RS, Gandara DR, Hirsch FR, et al. Lung Master Protocol (Lung-MAP)-a biomarker-driven protocol for accelerating development of therapies for squamous cell lung cancer: SWOG S1400. Clin Cancer Res. 2015;21(7):1514-1524. doi:10.1158/1078-0432.CCR-13-3473

77. Jotte R, Cappuzzo F, Vynnychenko I, et al. Atezolizumab in combination with carboplatin and Nab-paclitaxel in advanced squamous NSCLC (IMpower131): results from a randomized phase III trial. J Thorac Oncol. 2020;15(8):1351-1360. doi:10.1016/j.jtho.2020.03.028

78. Herbst R, Arkenau H, Bendell J, et al. MA14.07 Phase I expansion cohort of ramucirumab plus pembrolizumab in advanced treatment-naive non-small cell lung cancer (JVDF). IASCLC 2019 World Conference on Lung Cancer September 7-10; 2019; Barcelona, Spain. [abstract].

79. Han B, Chu T, Zhong H, et al. p1.01-95 efficacy and safety of anlotinib in combination with chemotherapy as first-line therapy in advanced non-small cell lung cancer (NSCLC) patients. IASCLC 2019 World Conference on Lung Cancer September 7-10; 2019; Barcelona, Spain. [abstract].

80. Wu Y-L, Huang C, Fan Y, et al. P1.01-61. A phase II umbrella study of camrelizumab in different PD-L1 expression cohorts in pre-treated advanced/metastatic non-small cell lung cancer. IASCLC 2019 World Conference on Lung Cancer September 7-10; 2019. Barcelona, Spain. [abstract].

81. Perol M. ES.01.04 Immunotherapy, radiotherapy and chemotherapy combination: a potential new standard? IASCLC 2019 World Conference on Lung Cancer September 7-10; 2019; Barcelona, Spain. [abstract].

82. Levy B, Paz-Ares L, Bennouna J, et al. Afatinib with pembrolizumab for treatment of patients with locally advanced/metastatic squamous cell carcinoma of the lung: the LUX-lung IO/KEYNOTE 497 study protocol. Clin Lung Cancer. 2019;20(3):e407-e412. doi:10.1016/j. cllc. 2018.12 .022

83. Garon EB, Hellmann MD, Rizvi NA, et al. Five-year overall survival for patients with advanced nonsmall-cell lung cancer treated with pembrolizumab: results from the phase I KEYNOTE-001 study. J Clin Oncol. 2019;37(28):2518-2527. doi:10.1200/JCO.19.00934

OncoTargets and Therapy

\section{Publish your work in this journal}

OncoTargets and Therapy is an international, peer-reviewed, open access journal focusing on the pathological basis of all cancers, potential targets for therapy and treatment protocols employed to improve the management of cancer patients. The journal also focuses on the impact of management programs and new therapeutic

Submit your manuscript here: https://www.dovepress.com/oncotargets-and-therapy-journal
84. Herbst RS, Baas P, Kim DW, et al. Pembrolizumab versus docetaxel for previously treated, PD-L1-positive, advanced non-small-cell lung cancer (KEYNOTE-010): a randomised controlled trial. Lancet. 2016;387(10027):1540-1550. doi:10.1016/S0140-6736(15)01281-7

85. Eli Lilly and Company. CYRAMZA ${ }^{\circledR}$ (ramucirumab). Highlights of prescribing information. Revised July, 2019.

86. Schoenfeld AJ, Arbour KC, Rizvi H, et al. Severe immune-related adverse events are common with sequential PD-(L)1 blockade and osimertinib. Ann Oncol. 2019;30(5):839-844. doi:10.1093/annonc/mdz077

87. van Putten JW, Baas P, Codrington H, et al. Activity of single-agent gemcitabine as second-line treatment after previous chemotherapy or radiotherapy in advanced non-small-cell lung cancer. Lung Cancer. 2001;33(2-3):289-298. doi:10.1016/S0169-5002(01)00188-X

88. Crino L, Mosconi AM, Scagliotti G, et al. Gemcitabine as second-line treatment for advanced non-small-cell lung cancer: a phase II trial. J Clin Oncol. 1999;17(7):2081-2085. doi:10.1200/ JCO.1999.17.7.2081

89. Sculier JP, Lafitte JJ, Berghmans T, et al. A phase II trial testing gemcitabine as second-line chemotherapy for non small cell lung cancer. The European Lung Cancer Working Party. 101473.1044@compuserve.com. Lung Cancer. 2000;29(1):67-73. doi:10.1016/S0169-5002(00)00099-4

90. Schiller JH, Harrington D, Belani CP, et al. Comparison of four chemotherapy regimens for advanced non-small-cell lung cancer. $N$ Engl J Med. 2002;346(2):92-98. doi:10.1056/NEJMoa011954

91. Perol M, Chouaid C, Perol D, et al. Randomized, phase III study of gemcitabine or erlotinib maintenance therapy versus observation, with predefined second-line treatment, after cisplatin-gemcitabine induction chemotherapy in advanced non-small-cell lung cancer. J Clin Oncol. 2012;30(28):3516-3524. doi:10.1200/JCO.2011.39.9782

92. Reck M, Rodriguez-Abreu D, Robinson AG, et al. Pembrolizumab versus chemotherapy for PD-L1-positive non-small-cell lung cancer. NEngl J Med. 2016;375(19):1823-1833. doi:10.1056/NEJMoa1606774

93. Reck M, Rodriguez-Abreu D, Robinson AG, et al. Updated analysis of KEYNOTE-024: pembrolizumab versus platinum-based chemotherapy for advanced non-small-cell lung cancer with PD-L1 tumor proportion score of $50 \%$ or greater. J Clin Oncol. 2019;37 (7):537-546. doi:10.1200/JCO.18.00149

94. Paz-Ares L, Luft A, Vicente D, et al. Pembrolizumab plus chemotherapy for squamous non-small-cell lung cancer. $N$ Engl $\mathrm{J} \mathrm{Med.}$ 2018;379(21):2040-2051. doi:10.1056/NEJMoa1810865

95. Hirsh V. New developments in the treatment of advanced squamous cell lung cancer: focus on afatinib. Onco Targets Ther. 2017;10:2513-2526. doi:10.2147/OTT.S104177

96. Harding J, Burtness B. Cetuximab: an epidermal growth factor receptor chemeric human-murine monoclonal antibody. Drugs Today (Barc). 2005;41(2):107-127. doi:10.1358/dot.2005.41.2.882662 agents and protocols on patient perspectives such as quality of life, adherence and satisfaction. The manuscript management system is completely online and includes a very quick and fair peer-review system, which is all easy to use. Visit http://www.dovepress.com/ testimonials.php to read real quotes from published authors. 